\title{
Transactions
}

Cite this: Dalton Trans., 2011, 40, 2622

wWw.rsc.org/dalton

PAPER

\section{Lewis base character of the phosphorus atom in phosphanido-niobocene complexes. Synthesis of new early-early homo- and heterobimetallic entities $\uparrow$}

\author{
R. Reguillo-Carmona, A. Antiñolo, * S. García-Yuste, I. López-Solera and A. Otero* \\ Received 19th July 2010, Accepted 9th December 2010 \\ DOI: 10.1039/c0dt00865f
}

The reaction of phosphanido complexes $\left[\mathrm{Nb}\left(\eta^{5}-\mathrm{C}_{5} \mathrm{H}_{4} \mathrm{SiMe}_{3}\right)_{2}(\mathrm{~L})\left(\mathrm{PPh}_{2}\right)\right][\mathrm{L}=\mathrm{CO}(\mathbf{1})$, CNXylyl (2) ] with early transition metal halides in high oxidation states has been carried out. New bimetallic niobocene complexes $\left[\left\{\mathrm{Nb}\left(\eta^{5}-\mathrm{C}_{5} \mathrm{H}_{4} \mathrm{SiMe}_{3}\right)_{2}(\mathrm{~L})\right\}\left(\mu-\mathrm{PPh}_{2}\right)\left(\mathrm{MCl}_{5}\right)\right][\mathrm{M}=\mathrm{Nb}, \mathrm{L}=\mathrm{CO}(3), \mathrm{L}=\mathrm{CNXylyl}(4) ; \mathrm{M}=$ $\mathrm{Ta}, \mathrm{L}=\mathrm{CO}(\mathbf{5}), \mathrm{L}=\mathrm{CNXylyl}(\mathbf{6})]$ have been successfully synthesized by the reaction with $\left[\mathrm{MCl}_{5}\right]_{2}(\mathrm{M}=$ $\mathrm{Nb}$ or Ta). In a similar way $\left[\left\{\mathrm{Nb}\left(\eta^{5}-\mathrm{C}_{5} \mathrm{H}_{4} \mathrm{SiMe}_{3}\right)_{2}(\mathrm{~L})\right\}\left(\mu-\mathrm{PPh}_{2}\right)\left(\mathrm{MCl}_{4}\right)\right][\mathrm{M}=\mathrm{Ti}, \mathrm{L}=\mathrm{CO}(\mathbf{1 3})$, CNXylyl (14); $\mathrm{M}=\mathrm{Zr}, \mathrm{L}=\mathrm{CO}(\mathbf{1 5})$, CNXylyl (16)] were synthesized using $\mathrm{MCl}_{4}(\mathrm{M}=\mathrm{Ti}$ or $\mathrm{Zr})$. Solutions of complexes 4-6 in chloroform produced new ionic derivatives $\left[\mathrm{Nb}\left(\eta^{5}-\mathrm{C}_{5} \mathrm{H}_{4} \mathrm{SiMe}_{3}\right)_{2}\left(\mathrm{P}(\mathrm{H}) \mathrm{Ph}_{2}\right)(\mathrm{L})\right]\left[\mathrm{MCl}_{6}\right]$ $[\mathrm{M}=\mathrm{Nb}, \mathrm{L}=\mathrm{CO}(\mathbf{7}), \mathrm{L}=\mathrm{CNXylyl}(\mathbf{8}) ; \mathrm{M}=\mathrm{Ta}, \mathrm{L}=\mathrm{CO}(\mathbf{9}), \mathrm{L}=\mathrm{CNXylyl}$ (10)]. Ionic complexes $\left[\mathrm{Nb}\left(\eta^{5}-\mathrm{C}_{5} \mathrm{H}_{4} \mathrm{SiMe}_{3}\right)_{2}\left(\mathrm{P}(\mathrm{Cl}) \mathrm{Ph}_{2}\right)(\mathrm{L})\right]\left[\mathrm{NbCl}_{4} \mathrm{O}(\mathrm{thf})\right][\mathrm{L}=\mathrm{CO}(\mathbf{1 1}), \mathrm{CNXylyl}(\mathbf{1 2})]$ were formed from solutions in thf - rapidly in the case of $\mathbf{3}$ but more slowly for $\mathbf{4}$. New heterometallic complexes $\left[\mathrm{Nb}\left(\eta^{5}-\mathrm{C}_{5} \mathrm{H}_{4} \mathrm{SiMe}_{3}\right)_{2}(\mathrm{~L})\left(\mu-\mathrm{PPh}_{2}\right)\left\{\left(\mathrm{Ti}\left(\eta^{5}-\mathrm{C}_{5} \mathrm{R}_{5}\right) \mathrm{Cl}_{3}\right\}\right]\left[\mathrm{R}=\mathrm{H}, \mathrm{L}=\mathrm{CO}(\mathbf{1 7}), \mathrm{CNXylyl}(\mathbf{1 8}) ; \mathrm{R}=\mathrm{CH}_{3}, \mathrm{~L}=\right.\right.$ $\mathrm{CO}$ (19), CNXylyl (20)] were synthesized by the reaction of $\mathbf{1}$ or $\mathbf{2}$ with $\left[\mathrm{Ti}\left(\eta^{5}-\mathrm{C}_{5} \mathrm{R}_{5}\right) \mathrm{Cl}_{3}\right](\mathrm{R}=\mathrm{H}$ or $\mathrm{CH}_{3}$ ). All of these compounds were characterized by IR and multinuclear NMR spectroscopy, and the molecular structures of $\mathbf{9}$ and $\mathbf{1 2}$ were determined by single-crystal X-ray diffraction.

\section{Introduction}

In the last three decades the chemistry of early/late heterobimetallic complexes (ELHBs) has been extensively developed, ${ }^{1}$ mainly due to the synergistic effect produced in this type of system by the simultaneous presence of a hard Lewis acid early-metal centre and a soft Lewis base late-metal centre. In this field, phosphanidobridged heterobimetallic compounds are well documented and in a good rational approach they have been prepared by the incorporation of an appropriate late metal moiety into a metallophosphide, $\mathrm{MPR}_{2}$, unit of the early transition metal. The first examples of this type of complex were described several years ago by Stelzer et al. ${ }^{2}$ Although most of the complexes have been based on group 4 phosphanido-containing moieties, ${ }^{3}$ similar types of complexes containing group 5 metal moieties have been prepared, particularly in the pioneering work of Moïse et al. in the 1990s, by using both niobocene(tantalocene)-phosphanido systems and $\mathrm{M}(\mathrm{CO})_{x}$ $(\mathrm{M}=\mathrm{Fe}, \mathrm{Mo}, \mathrm{W})$ as building blocks. ${ }^{4}$ More recently, Nikonov et al. ${ }^{5}$ used an imido-phosphanido niobocene for the construction of $\mathrm{Nb} / \mathrm{Rh}$ heterobimetallic complexes that have proven to be active precatalysts for the hydrosilylation of ketones and aldehydes. In addition, Hey-Hawkins et $a l^{6}$ have prepared a series of dimeric phosphinidene-bridged $\mathrm{Ta}^{\mathrm{v}}$ complexes, a rare example of homobimetallic group 5 species containing bridged-phosphanido

Dpto. de Química Inorgánica, Org. y Bioq., Facultad de Químicas, Universidad de Castilla La Mancha, 13071, Ciudad Real, Spain

$\dagger$ CCDC reference numbers 784737 and 784738 . For crystallographic data in CIF or other electronic format see DOI: $10.1039 / \mathrm{c} 0 \mathrm{dt} 00865 \mathrm{f}$ or related moieties. In the last decade we have developed a series of studies focused on the reactivity of phosphanido-containing niobocene complexes; thus, the insertion reaction of carbon disulfide into the $\mathrm{Nb}-\mathrm{P}$ bond gave a series of new niobocene complexes that contained the anionic phosphanylthioformato ligand $\mathrm{R}_{2} \mathrm{PCS}_{2}{ }^{-}{ }^{7}$ More recently, we described the preparation of a series of niobacycles that involved the insertion reaction of electron-deficient alkynes into the $\mathrm{Nb}-\mathrm{P}$ bond. ${ }^{8}$ We became interested in analyzing the behavior of our phosphanido-containing niobocene complexes as metallophosphides towards group 4 and 5 metal moieties in order to prepare new types of hetero- and homobimetallic early-early organometallic entities.

Herein we report the synthesis of several new dinuclear $\mathrm{d}^{2}-$ $\mathrm{d}^{0}$, homo- and heterobimetallic mono-bridged complexes $[\mathrm{Nb}(\mu$ $\left.\left.\mathrm{PPh}_{2}\right) \mathrm{M}\right](\mathrm{M}=\mathrm{Nb}, \mathrm{Ta}, \mathrm{Ti}, \mathrm{Zr})$. This approach takes advantage of the ability of the niobium(III) phosphanido complexes [ $\mathrm{Nb}\left(\eta^{5}\right.$ $\left.\left.\mathrm{C}_{5} \mathrm{H}_{4} \mathrm{SiMe}_{3}\right)_{2}(\mathrm{~L})\left(\mathrm{PPh}_{2}\right)\right](\mathbf{1}$ and 2) to act as Lewis bases toward a series of halide group 4 and 5 transition metal species $\mathrm{MCl}_{x}$ that can act as Lewis acids.

\section{Results and discussion}

The reaction of toluene solutions of $\mathbf{1}$ or $\mathbf{2}$ with the Lewis acids $\left(\mathrm{MCl}_{5}\right)_{2}$, where $\mathrm{M}=\mathrm{Nb}$ or Ta, gave the new bimetallic complexes 3-6 as red solids, in which the two metals on each complex are in a different oxidation state, i.e. $\mathrm{Nb}(\mathrm{III})$ and $\mathrm{M}(\mathrm{V})$. $\mathrm{TiCl}_{4}$ and $\mathrm{ZrCl}_{4}$ yielded the heterobimetallic complexes 13-16 and with monocyclopentadienyl Ti(IV) trichloride the new complexes 

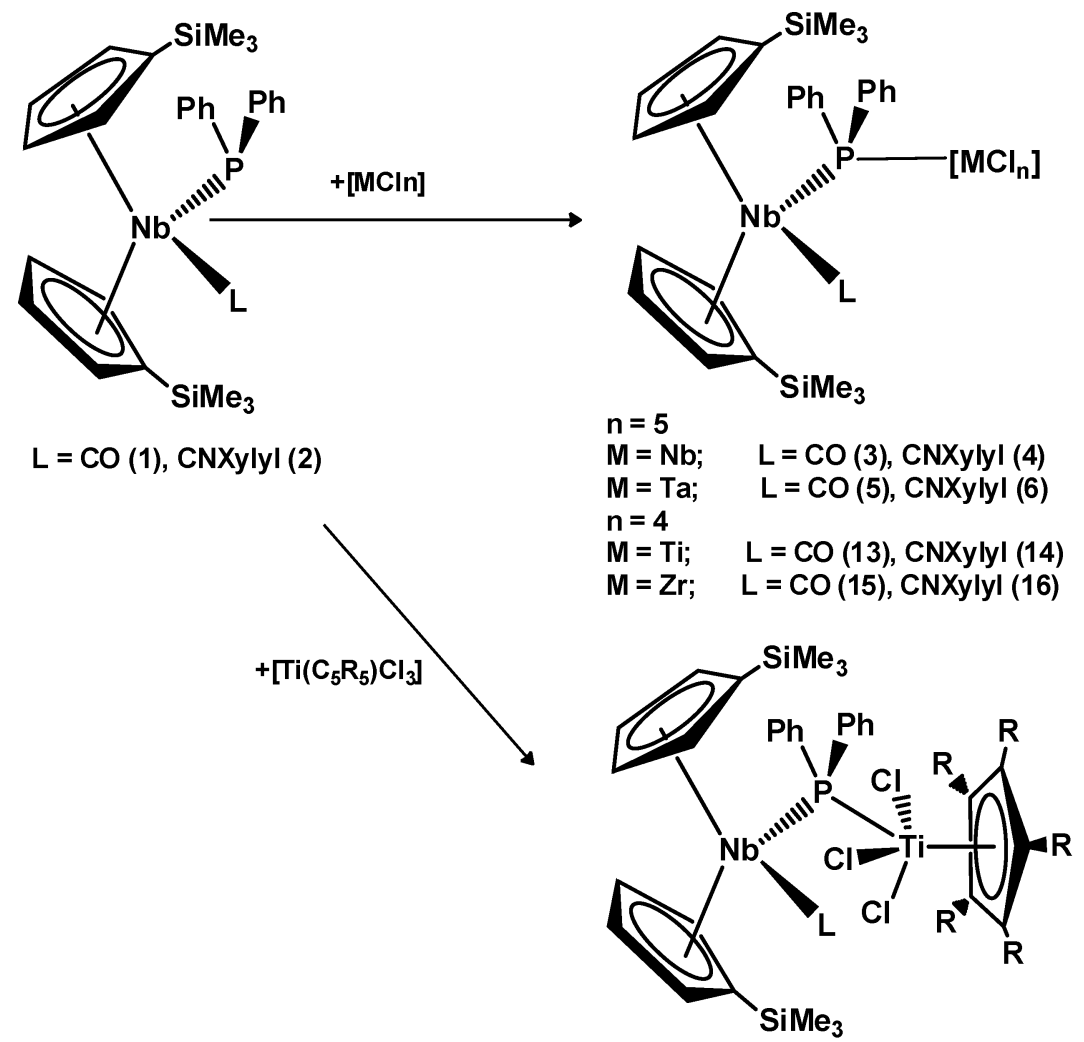

$\mathrm{R}=\mathrm{H} ; \quad \mathrm{L}=\mathrm{CO}(17)$, CNXylyl (18)

$\mathrm{R}=\mathrm{CH}_{3} ; \quad \mathrm{L}=\mathrm{CO}(19)$, CNXylyl (20)

Scheme 1

17-20 were isolated as orange-red solids in high yield after the appropriate workup (see Scheme 1).

Complexes 4-6 and 13-20 were characterized by elemental analysis, IR and multinuclear NMR spectroscopy in solution.

The low solubility of complex $\mathbf{3}$ in hydrocarbons, ethers or aromatic solvents and its high reactivity toward chloroform or dichloromethane precluded characterization by NMR techniques.

The IR spectra for $3, \mathbf{5}, \mathbf{1 3}, \mathbf{1 5}, \mathbf{1 7}$ and 19 contain a characteristic band due to the carbonyl ligand $v(\mathrm{C} \equiv \mathrm{O})$ at $1950(1949-1956) \mathrm{cm}^{-1}$ (a typical value for niobium(III) metallocenes ${ }^{7}$ ), and for 4, 6, 14, $\mathbf{1 6}, \mathbf{1 8}$, and 20 there is a band corresponding to the isocyanide $v(\mathrm{C} \equiv \mathrm{N})$ at $2060(2073-2050) \mathrm{cm}^{-1}$.

The ${ }^{31} \mathrm{P}\left\{{ }^{1} \mathrm{H}\right\}$ NMR spectra of these complexes in deuterated chloroform show a single broad signal for each complex, at $27.4 \mathrm{ppm}$ for 4, $29.9 \mathrm{ppm}$ for 5 and $77.3 \mathrm{ppm}$ for $\mathbf{6}$. These resonances were shifted downfield with respect to those of the phosphanido ligand in complexes $\mathbf{1}$ or $\mathbf{2}$. This change is consistent with the expected decrease in electron density on the phosphorus atom upon coordination to another metal centre. Furthermore, all the resonances are in the expected region for a phosphanido bridge with donation of the phosphanido lone pair to some of the empty orbitals in $\mathrm{MCl}_{5}(\mathrm{M}=\mathrm{Nb}$ or Ta). Two conformational dispositions are possible in the bimetallic complexes as a consequence of this interaction (Scheme 2); the exo conformer in which the new $\mathrm{MCl}_{5}$ entity is located away from the niobocene moiety, and the endo conformer in which this moiety and the metallic halide are closer and may interact to form a new metal-metal bond. These

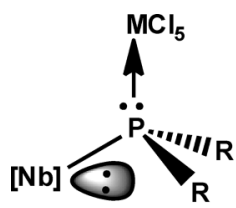

Exo

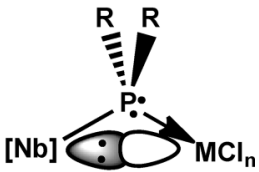

Endo
$[\mathrm{Nb}]=\left[\mathrm{Nb}\left(\eta^{5}-\mathrm{C}_{5} \mathrm{H}_{4} \mathrm{SiMe}_{3}\right)_{2} \mathrm{~L}\right] \quad \mathrm{L}=\mathrm{CO}$ or CNXylyl

Scheme 2

conformational preferences have been described previously ${ }^{4 a, 9}$ and can be distinguished by the ${ }^{31} \mathrm{P}$ NMR chemical shift. In fact, in all cases where the metal-metal bond exists the chemical shift of the signal for the phosphorus is found between +300 and $50 \mathrm{ppm}$, whereas when a metal-metal bond does not exist this signal appears between +50 and -300 ppm.

The ${ }^{31} \mathrm{P}$ NMR chemical shifts found for $\mathbf{4}$ and $\mathbf{5}$ are in the region corresponding to the exo conformer. However, in the case of $\mathbf{6}$ the observed value is in the boundary region for the two conformers, and it is not possible to distinguish between the two possibilities.

However, the chemical shifts of the signals observed in the ${ }^{31} \mathrm{P}\left\{{ }^{1} \mathrm{H}\right\}$ NMR spectra of complexes 13, 14 and $\mathbf{1 6}(157.2,166.1$ and $165.8 \mathrm{ppm}$, respectively) are consistent ${ }^{4 a, 9}$ with an interaction between the lone pair of the niobium(III) atom and the empty orbital of the other metal centre, as shown in Scheme 3 II. This additional metal-metal bonding interaction must provide 


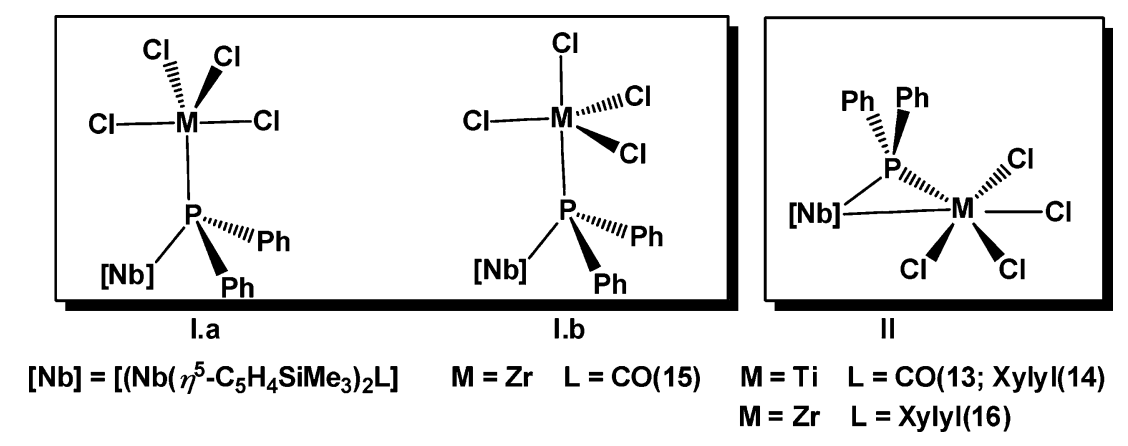

Scheme 3

further stabilization for these complexes, in which the coordination number of $\mathrm{Ti}$ or $\mathrm{Zr}$ can be increased to six. In the case of complex 15 the value of the chemical shift for phosphorus is $28.7 \mathrm{ppm}$, which indicates that an interaction does not occur between the two metal centres, as shown in the Scheme 2 I. This situation could be because the lone pair of the $\mathrm{d}^{2}$ niobocene system is mainly involved in $\pi$ back-donation to the carbonyl ancillary ligand and an additional $\mathrm{Nb}-\mathrm{Zr}$ interaction is therefore probably not present in complex 15. Assuming an exo conformation for this complex (see Scheme 1), the zirconium centre increases its coordination number to five (bpt), and two isomers are possible (I.a and I.b, see Scheme 3).

There are few examples where the coordination number of five appears for titanium(IV) or zirconium(IV) complexes, and in these cases it displays a coordination environment intermediate between square-pyramidal and trigonal-bipyramidal. ${ }^{10}$

In the case of complexes 17-20 the ${ }^{31} \mathrm{P}\left\{{ }^{1} \mathrm{H}\right\} \quad \mathrm{NMR}$ are particularly informative, since the chemical shifts observed between 12.8 and $26.6 \mathrm{ppm}$ (see Experimental section) are consistent ${ }^{4 a, 9}$ with a structural disposition bearing a phosphanido bridge between the two metal centres without any additional interaction.

The ${ }^{1} \mathrm{H}$ NMR spectra of complexes 4-6 and 13-20 provide evidence for the $C_{\mathrm{s}}$ symmetry of the niobocene moiety, and contain a singlet for the methyl groups of the $\mathrm{SiMe}_{3}$ at $c a .0 .20 \mathrm{ppm}$ and four multiplets corresponding to the cyclopentadienyl protons, which adopt an ABCD spin system, in the range 4.58-5.80 ppm. The ${ }^{1} \mathrm{H}$ NMR spectra of 4-6 and 13-20 also contain signals corresponding to the phenyl groups, and the spectra of $4,6,14,16$, 18 and 20 contain a singlet for the methyl groups of the CNXylyl at $c a .2 .3 \mathrm{ppm}$ and a multiplet at $c a .7 .3 \mathrm{ppm}$ for the phenyl ring of the same group.
Furthermore, the ${ }^{1} \mathrm{H}$ NMR spectra of $\mathbf{1 7}$ and $\mathbf{2 0}$ each contain a singlet signal at $c a$. $6.71 \mathrm{ppm}$ corresponding to the $\mathrm{C}_{5} \mathrm{H}_{5}$ fragment for 17 and 18 or a signal at $c a .2 .19$ ppm corresponding to the methyl group of the $\mathrm{C}_{5} \mathrm{Me}_{5}$ unit for $\mathbf{1 8}$ and $\mathbf{2 0}$.

The spectroscopic data are all consistent with the structural disposition depicted in Scheme 1, where the two metal centres are connected by a phosphanido-bridging moiety bearing the niobocene unit as a metallophosphide coordinated to the titanium centre, which exhibits the well known four-legged piano-stool structure. ${ }^{11}$

The low stability in solution of complexes 3-6 precludes their characterization by ${ }^{13} \mathrm{C}\left\{{ }^{1} \mathrm{H}\right\} \mathrm{NMR}$; in fact, solutions of complex 3-6 in chloroform give rise to new ionic derivatives $\left[\mathrm{Nb}\left(\eta^{5}\right.\right.$ $\left.\left.\mathrm{C}_{5} \mathrm{H}_{4} \mathrm{SiMe}_{3}\right)_{2}\left(\mathrm{P}(\mathrm{H}) \mathrm{Ph}_{2}\right)(\mathrm{L})\right]\left[\mathrm{MCl}_{6}\right][\mathrm{M}=\mathrm{Nb} ; \mathrm{L}=\mathrm{CO}(7)$, CNXylyl (8); $\mathrm{M}=\mathrm{Ta}, \mathrm{L}=\mathrm{CO}(\mathbf{9})$, CNXylyl (10)], probably due to attack by $\mathrm{HCl}$ arising from the solvent. In fact when complex 3-6 were solved in deuterated chloroform, the deuterated phosphonium complexes was identified by NMR; thus, the ${ }^{31} \mathrm{P}$ NMR spectrum shows a $1: 1: 1$ triplet resonance due to coupling with the deuterium atom $\left({ }^{1} J_{\mathrm{PD}} c a .34 \mathrm{~Hz}\right)$. This signal allowed us to confirm the existence of the $\mathrm{P}-\mathrm{D}$ bond as reported previously. ${ }^{7 \mathrm{a}}$

The ionic nature of complexes 7-10 was confirmed by conductivity measurements on solutions of the complexes in acetone. The values obtained were between 116 and $121 \Omega^{-1} \mathrm{~cm}^{2} \mathrm{~mol}^{-1}$ and these are consistent with $1: 1$ electrolytes. $^{12}$

The spectroscopic data for complexes 7-10 [IR, ${ }^{31} \mathrm{P}\left\{{ }^{1} \mathrm{H}\right\}$ NMR, ${ }^{1} \mathrm{H}$ and ${ }^{13} \mathrm{C}\left\{{ }^{1} \mathrm{H}\right\}$ NMR spectra] are consistent with the formula $\left[\mathrm{Nb}\left(\eta^{5}-\mathrm{C}_{5} \mathrm{H}_{4} \mathrm{SiMe}_{3}\right)_{2}\left(\mathrm{P}(\mathrm{H}) \mathrm{Ph}_{2}\right)(\mathrm{L})\right]^{+}(\mathrm{L}=\mathrm{CO}, \mathrm{CNXylyl})$, as reported previously. ${ }^{7 \mathrm{a}}$ In fact, these cations can also be synthesized by reaction of $\left[\mathrm{Nb}\left(\eta^{5}-\mathrm{C}_{5} \mathrm{H}_{4} \mathrm{SiMe}_{3}\right)_{2}\left(\mathrm{P}(\mathrm{H}) \mathrm{Ph}_{2}\right)(\mathrm{L})\right] \mathrm{Cl}(\mathrm{L}=\mathrm{CO}$, $\mathrm{CNXylyl})^{7 \mathrm{a}}$ with $\left[\mathrm{MCl}_{5}\right]_{2}(\mathrm{M}=\mathrm{Nb}$ or Ta) in chloroform (Scheme 4). Additionally, complex 9 was characterized by X-ray diffraction.

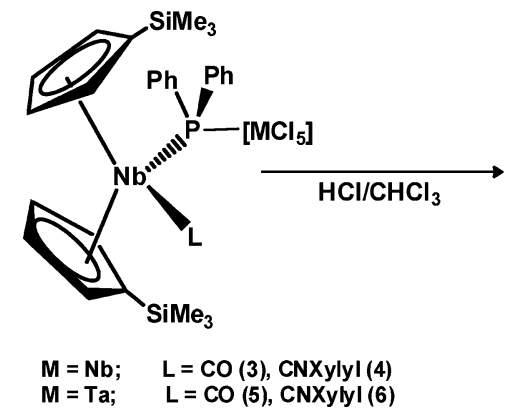

$\begin{array}{ll}M=N b ; & L=C O(3), \text { CNXylyl (4) } \\ M=T a ; & L=C O(5), \text { CNXylyl (6) }\end{array}$

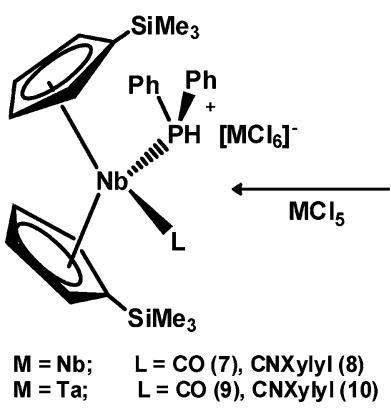

Scheme 4

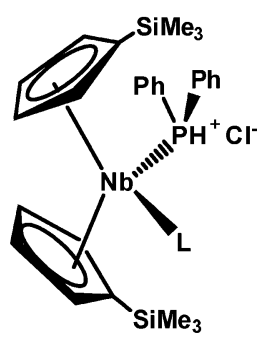


Table 1 Selected bond lengths $(\AA)$ and angles $\left({ }^{\circ}\right)$ for complex 9

\begin{tabular}{llll}
\hline Bond lengths $(\AA)$ & & Bond angles $\left(^{\circ}\right)$ \\
\hline $\mathrm{Nb}(1)-\mathrm{Cp}(1)^{a}$ & 2.07 & $\mathrm{Cent}(1)-\mathrm{Nb}-\mathrm{Cent}(2)^{b}$ & 140.4 \\
$\mathrm{Nb}(1)-\mathrm{Cp}(2)^{a}$ & 2.06 & $\mathrm{C}(1)-\mathrm{Nb}(1)-\mathrm{P}(1)$ & $82.9(10)$ \\
$\mathrm{Nb}(1)-\mathrm{C}(1)$ & $2.11(4)$ & $\mathrm{Nb}(1)-\mathrm{P}(1)-\mathrm{C}(31)$ & $117.6(8)$ \\
$\mathrm{Nb}(1)-\mathrm{P}(1)$ & $2.56(1)$ & $\mathrm{Nb}(1)-\mathrm{P}(1)-\mathrm{C}(41)$ & $122.5(8)$ \\
$\mathrm{C}(1)-\mathrm{O}(1)$ & $1.14(4)$ & $\mathrm{C}(31)-\mathrm{P}(1)-\mathrm{C}(41)$ & $104.2(12)$ \\
$\mathrm{P}(1)-\mathrm{C}(31)$ & $1.81(3)$ & $\mathrm{Cl}(1)-\mathrm{Ta}(1)-\mathrm{Cl}(2)$ & $178.0(3)$ \\
$\mathrm{P}(1)-\mathrm{C}(41)$ & $1.80(2)$ & $\mathrm{Cl}(1)-\mathrm{Ta}(1)-\mathrm{Cl}(3)$ & $88.8(4)$ \\
$\mathrm{Ta}(1)-\mathrm{Cl}(1)$ & $2.33(1)$ & $\mathrm{Cl}(1)-\mathrm{Ta}(1)-\mathrm{Cl}(4)$ & $89.2(4)$ \\
$\mathrm{Ta}(1)-\mathrm{Cl}(2)$ & $2.35(1)$ & $\mathrm{Cl}(1)-\mathrm{Ta}(1)-\mathrm{Cl}(5)$ & $91.4(4)$ \\
$\mathrm{Ta}(1)-\mathrm{Cl}(3)$ & $2.32(1)$ & $\mathrm{Cl}(2)-\mathrm{Ta}(1)-\mathrm{Cl}(3)$ & $89.9(4)$ \\
$\mathrm{Ta}(1)-\mathrm{Cl}(4)$ & $2.32(1)$ & $\mathrm{Cl}(2)-\mathrm{Ta}(1)-\mathrm{Cl}(4)$ & $89.3(3)$ \\
$\mathrm{Ta}(1)-\mathrm{Cl}(5)$ & $2.30(1)$ & $\mathrm{Cl}(3)-\mathrm{Ta}(1)-\mathrm{Cl}(4)$ & $92.2(3)$ \\
$\mathrm{Ta}(1)-\mathrm{Cl}(6)$ & $2.37(1)$ & $\mathrm{Cl}(4)-\mathrm{Ta}(1)-\mathrm{Cl}(5)$ & $176.9(5)$
\end{tabular}

${ }^{a}$ Refers to the average bond distance between $\mathrm{Nb}(1)$ and the carbon atoms of the $\mathrm{C}_{5}$ ring of the corresponding cyclopentadienyl moiety. ${ }^{b} \mathrm{Cent}(1)$ and Cent(2) are the centroids of $\mathrm{C}(11)-\mathrm{C}(15)$ and $\mathrm{C}(21)-\mathrm{C}(25)$, respectively.

A microcrystalline sample of $\mathbf{9}$, which was suitable for $\mathrm{X}$ ray diffraction, was obtained by crystallization from chloroform. Structure is depicted in Fig. 1. Selected bond distances and angles are listed in Table 1.

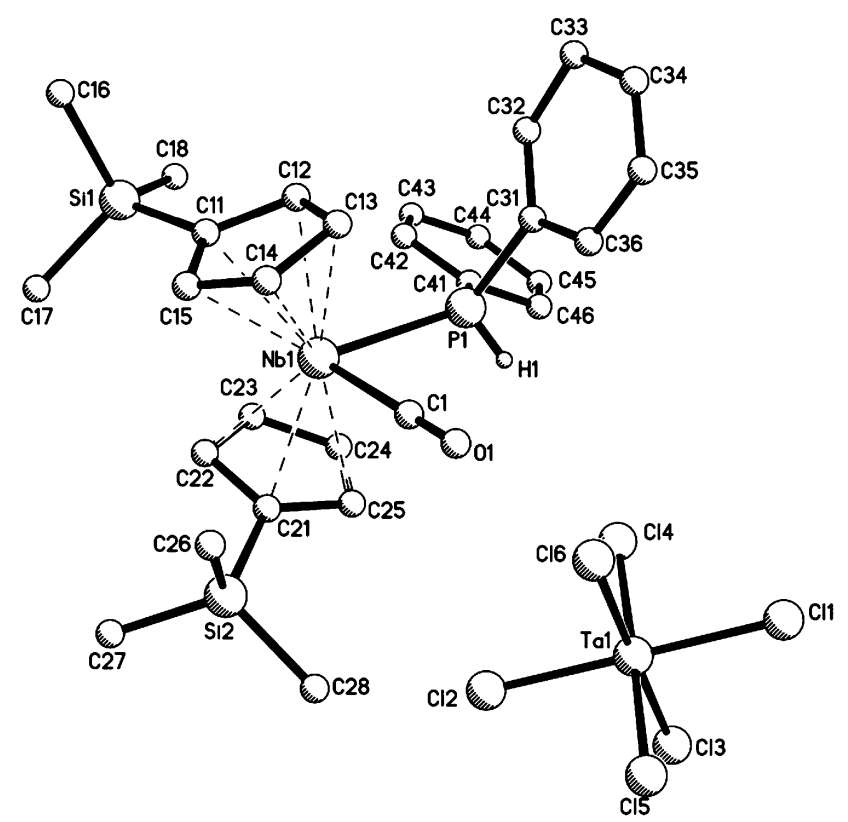

Fig. 1 Structure of complex 9. Hydrogen atoms (except H1) have been omitted for clarity.

The structure of 9 shows the typical bent metallocene conformation with both cyclopentadienyl rings bound to the metal centre in a $\eta^{5}$ fashion. The niobium atom is also coordinated to the phosphane and the carbonyl ligands. The niobium-carbon bond length (carbonyl ligand), $\mathrm{Nb}(1)-\mathrm{C}(1)$, is 2.11(4) Å, which is in the range found for other metallocene complexes with terminal carbonyl ligands. ${ }^{7}$ The carbonyl ligand is linear, with an $\mathrm{O}(1)-\mathrm{C}(1)-\mathrm{Nb}(1)$ angle of $174(3)^{\circ}$ and an $\mathrm{O}(1)-\mathrm{C}(1)$ distance of 1.14(4) $\AA$, both values that are close to those found for the terminal carbonyl ligand in other niobocene complexes. ${ }^{7}$

The phosphorus atom is in a distorted tetrahedral environment, and the $\mathrm{Nb}(1)-\mathrm{P}(1)$ bond length of $2.56(1) \AA$ is similar to those found in other niobium-phosphane complexes previously reported by our group. ${ }^{7}$

The positive charge of the metallocene is stabilized by the hexachlorotantalate(v) anion, in which the tantalum atom has an octahedral geometry. ${ }^{13}$

The characterization of the niobiocene cation has already been described by our group through different spectroscopic techniques, ${ }^{7}$ but this structure represents the first example of a diphenylphosphanyl-niobiocene species to be characterized by Xray diffraction.

The behavior of the Lewis acid $\left[\mathrm{NbCl}_{5}\right]_{2}$ in thf solution has recently been reported, ${ }^{14}$ and it was found that the niobium(v) centre promoted activation of the thf. As a result, we assessed the ability of complexes $\mathbf{3}$ and $\mathbf{4}$ to interact with this solvent. Thus, dissolution of $\mathbf{3}$ and $\mathbf{4}$ in thf at room temperature led to the formation of a precipitate after a reaction time of $30 \mathrm{~min}$ in each case. The appropriate workup led to the isolation of red solids, which were identified as complexes 11 and 12 (eqn (1)).

$$
\begin{aligned}
& {\left[\left\{\mathrm{Nb}\left(\eta^{5}-\mathrm{C}_{5} \mathrm{H}_{4} \mathrm{SiMe}_{3}\right)_{2}(\mathrm{~L})\left(\mu-\mathrm{PPh}_{2}\right)\right\}\left(\mathrm{MCl}_{5}\right)\right] \stackrel{\text { thf }}{\longrightarrow}} \\
& {\left[\mathrm{Nb}\left(\eta^{5}-\mathrm{C}_{5} \mathrm{H}_{4} \mathrm{SiMe}_{3}\right)_{2}\left(\mathrm{P}(\mathrm{Cl}) \mathrm{Ph}_{2}\right)(\mathrm{L})\right]\left[\mathrm{NbCl}_{4} \mathrm{O}(\text { thf })\right]} \\
& \text { where } \mathrm{L}=\mathrm{CO}(\mathbf{3}), \mathrm{CNXylyl}(\mathbf{4}), \mathrm{CO}(\mathbf{1 1}), \mathrm{CNXylyl}(\mathbf{1 2})
\end{aligned}
$$

Furthermore, the ionic complexes $\left[\mathrm{Nb}\left(\eta^{5}-\mathrm{C}_{5} \mathrm{H}_{4} \mathrm{SiMe}_{3}\right)_{2}-\right.$ $\left.\left(\mathrm{P}(\mathrm{Cl}) \mathrm{Ph}_{2}\right)(\mathrm{L})\right]\left[\mathrm{NbCl}_{4} \mathrm{O}(\mathrm{thf})\right][\mathrm{L}=\mathrm{CO}(\mathbf{1 1}), \mathrm{CNXylyl}(\mathbf{1 2})]$ were also isolated quickly from $\mathbf{1}$ or more slowly from $\mathbf{2}$ when solutions of these compounds in thf were treated with $\left[\mathrm{NbCl}_{5}\right]_{2}$ at room temperature; in this reaction the probably formed $\mathbf{3}$ or 4 undergoes the halogenations of the phosphorous atom to give the corresponding cationic chlorophosphane complexes, while the $\left[\mathrm{NbCl}_{4} \mathrm{O} \text { (thf) }\right]^{-}$is formed ${ }^{15}$ by the interaction with thf. In fact, as mentioned above, when $\mathbf{3}$ or $\mathbf{4}$ previously isolated were solved in thf at room temperature led to the formation of $\mathbf{1 1}$ or $\mathbf{1 2}$.

Complexes $\mathbf{1 1}$ and $\mathbf{1 2}$ were fully characterized by elemental analysis, IR and multinuclear NMR spectroscopy in solution. Complex 12 was also characterized by X-ray diffraction.

The ionic nature of complexes $\mathbf{1 1}$ and $\mathbf{1 2}$ was confirmed by conductivity measurements on solutions in acetone (see Experimental section). The spectroscopic data for $\mathbf{1 1}$ and $\mathbf{1 2}$ also confirm their ionic nature. For example, the ${ }^{31} \mathrm{P}\left\{{ }^{1} \mathrm{H}\right\}$ NMR spectra show a single broad signal at $27.1 \mathrm{ppm}$ for $\mathbf{1 1}$ and at $34.2 \mathrm{ppm}$ for $\mathbf{1 2}$ for the chlorophosphane ligand. These resonances were shifted downfield with respect to those in the corresponding phosphanido ligand in complexes 1 and 2, but at high field with respect to the signal at $80 \mathrm{ppm}$ presented by free ${ }^{16} \mathrm{PClPh}_{2}$. These findings are consistent with the expected decrease in electron density on the phosphorus atom with respect to $\mathbf{1}$ and $\mathbf{2}$, and the increase in electron density with respect free $\mathrm{PClPh}_{2}$ by mean of the electron withdrawal from the niobium(III) centre. This behavior are in agreement with the ${ }^{31} \mathrm{P}$ chemical shift observed in other halophosphanes coordinated to niobium. ${ }^{\text {cc }}$

The IR spectra of complexes 11 and $\mathbf{1 2}$ contain the characteristic band due to the carbonyl ligand $\mathrm{v}(\mathrm{C} \equiv \mathrm{O})$ at $c a .1950 \mathrm{~cm}^{-1}$ for $\mathbf{1 1}$ and the band corresponding to $\mathrm{v}(\mathrm{C} \equiv \mathrm{N})$ at $c a .2067 \mathrm{~cm}^{-1}$ for $\mathbf{1 2}$. Additionally, a strong band was also observed at $c a .957 \mathrm{~cm}^{-1}$ in the expected region for $\mathrm{v}(\mathrm{Nb}=\mathrm{O}) .{ }^{17}$

The ${ }^{1} \mathrm{H}$ NMR spectra of complexes 11 and 12 evidence the lack of symmetry of the niobocene moiety and contain two singlets for the methyl groups of the two different $\mathrm{SiMe}_{3}$ groups at $c a .0 .25 \mathrm{ppm}$ 
and eight multiplets in the range 5.23-5.31 ppm corresponding to the two cyclopentadienyl protons, each of which adopts an ABCD spin system. The different NMR behavior of the two cyclopentadienyl ring might be due to hindered rotation about the $\mathrm{Nb}-\mathrm{P}$ bond or hindered rotation about the two $\mathrm{Cp}^{\prime}-\mathrm{Nb}$ axes; the rotation about the two $\mathrm{Cp}^{\prime}-\mathrm{Nb}$ axes could be hindered by steric reasons or some interaction between the terminal oxygen atom present in the anion $\left[\mathrm{NbCl}_{4} \mathrm{O}(\right.$ thf $\left.)\right]$ and one of the cyclopentadienyl rings through one of the methyl of the $\mathrm{SiMe}_{3}$ groups. This interaction has been also observed in the solid state in the Xray studies carried out for the complex 12. However, hindered rotation about the $\mathrm{Nb}-\mathrm{P}$ bond related to the bigger size of the chloride atom in comparison with the hydrogen atom must be taken into account.

Furthermore, the spectrum of $\mathbf{1 2}$ contains two signals for the methyl groups of the CNXylyl ligand at 2.34 and $2.50 \mathrm{ppm}$ and a multiplet at $c a .7 .3 \mathrm{ppm}$ for the phenyl ring; finally, in the spectra of 11 and 12 two resonances at 1.85 and $3.86 \mathrm{ppm}$ are observed, and these are due to the methylene protons of the thf coordinated to the niobium center.

The ${ }^{13} \mathrm{C}\left\{{ }^{1} \mathrm{H}\right\}$ NMR spectra of complexes $\mathbf{1 1}$ and $\mathbf{1 2}$ also provide evidence for the lack of symmetry of the niobocene moiety. Two singlets are observed for the carbon atoms of the $\mathrm{SiMe}_{3}$ groups and ten signals for the cyclopentadienyl rings. Signals due to the quaternary carbon atom of the ancillary ligand are not observed.

A red microcrystalline sample of $\mathbf{1 2}$, which was suitable for Xray diffraction, was obtained by crystallization from thf/hexane by cooling the solution at $-20^{\circ} \mathrm{C}$ for three days.

An ORTEP diagram of $\mathbf{1 2}$ is depicted in Fig. 2. Selected bond distances and angles are listed in Table 2.

The niobium atom has a distorted tetrahedral environment with two positions occupied by the cyclopentadienyl rings and the other two by the phosphane and the isocyanide ligands. ${ }^{7}$

The distance between the nitrogen and the carbon atoms of the isocyanide ligand, $\mathrm{N}(1)-\mathrm{C}(1) 1.17(1) \AA$, and the angle $\mathrm{N}(1)-$ $\mathrm{C}(1)-\mathrm{Nb}(1), 175.4(9)^{\circ}$, indicate the presence of a triple $\mathrm{C} \equiv \mathrm{N}$ bond and an almost linear coordination with the metal center. The $\mathrm{Nb}(1)-\mathrm{P}(1)$ bond length is in the range of values observed in other phosphane-niobocene complexes described previously by our group. ${ }^{7}$

Table 2 Selected bond lengths $(\AA)$ and angles $\left({ }^{\circ}\right)$ for complex 12

\begin{tabular}{llll}
\hline Bond lengths $(\AA)$ & \multicolumn{3}{l}{ Bond angles $\left(^{\circ}\right)$} \\
\hline $\mathrm{Nb}(1)-\mathrm{Cp}(1)^{a}$ & 2.05 & $\mathrm{Cent}(1)-\mathrm{Nb}(1)-\mathrm{Cent}(2)^{b}$ & 140.3 \\
$\mathrm{Nb}(1)-\mathrm{Cp}(2)^{a}$ & 2.06 & $\mathrm{P}(1)-\mathrm{Nb}(1)-\mathrm{C}(1)$ & $85.0(3)$ \\
$\mathrm{Nb}(1)-\mathrm{P}(1)$ & $2.55(1)$ & $\mathrm{Nb}(1)-\mathrm{P}(1)-\mathrm{Cl}(1)$ & $114.5(2)$ \\
$\mathrm{Nb}(1)-\mathrm{C}(1)$ & $2.13(1)$ & $\mathrm{Nb}(1)-\mathrm{P}(1)-\mathrm{C}(41)$ & $116.0(3)$ \\
$\mathrm{P}(1)-\mathrm{Cl}(1)$ & $2.04(1)$ & $\mathrm{Nb}(1)-\mathrm{P}(1)-\mathrm{C}(51)$ & $122.5(4)$ \\
$\mathrm{N}(1)-\mathrm{C}(1)$ & $1.17(1)$ & $\mathrm{Cl}(1)-\mathrm{P}(1)-\mathrm{C}(41)$ & $98.5(4)$ \\
$\mathrm{Nb}(2)-\mathrm{O}(1)$ & $1.69(1)$ & $\mathrm{Cl}(1)-\mathrm{P}(1)-\mathrm{C}(51)$ & $99.0(4)$ \\
$\mathrm{Nb}(2)-\mathrm{O}(2)$ & $2.39(1)$ & $\mathrm{C}(41)-\mathrm{P}(1)-\mathrm{C}(51)$ & $102.7(5)$ \\
$\mathrm{Nb}(2)-\mathrm{Cl}(2)$ & $2.38(1)$ & $\mathrm{C}(1)-\mathrm{N}(1)-\mathrm{C}(31)$ & $175.9(12)$ \\
$\mathrm{Nb}(2)-\mathrm{Cl}(3)$ & $2.39(1)$ & $\mathrm{Nb}(1)-\mathrm{C}(1)-\mathrm{N}(1)$ & $175.4(9)$ \\
$\mathrm{Nb}(2)-\mathrm{Cl}(4)$ & $2.37(1)$ & $\mathrm{O}(1)-\mathrm{Nb}(2)-\mathrm{O}(2)$ & $178.3(4)$ \\
$\mathrm{Nb}(2)-\mathrm{Cl}(5)$ & $2.41(1)$ & &
\end{tabular}

${ }^{a}$ Refers to the average bond distance between $\mathrm{Nb}(1)$ and the carbon atoms of the $\mathrm{C}_{5}$ ring of the corresponding cyclopentadienyl moiety. ${ }^{b}$ Cent $(1)$ and Cent(2) are the centroids of $C(11)-C(15)$ and $C(21)-C(25)$, respectively.

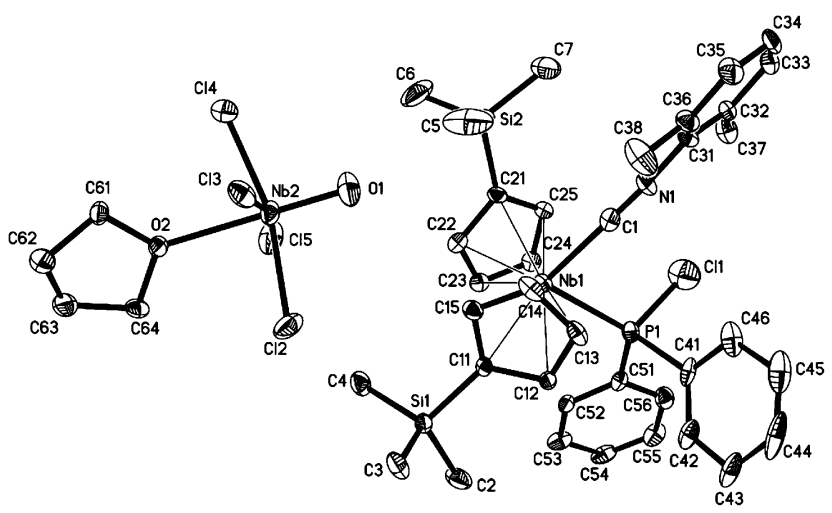

Fig. 2 ORTEP view of complex 12. Hydrogen atoms have been omitted for clarity. Thermal ellipsoids are drawn at the $20 \%$ probability level.

The phosphorus atom is also in a distorted tetrahedral environment, as indicated by the values of the angles formed by the phenyl rings and the chlorine atom; $\mathrm{C}(51)-\mathrm{P}(1)-\mathrm{Cl}(1) 99.0(4)^{\circ}, \mathrm{C}(41)-$ $\mathrm{P}(1)-\mathrm{Cl}(1) 98.5(4)^{\circ}, \mathrm{C}(41)-\mathrm{P}(1)-\mathrm{C}(51) 102.7(5)^{\circ}$ and $\mathrm{Nb}(1)-\mathrm{P}(1)-$ $\mathrm{Cl}(1) 114.5(2)^{\circ}$.

The positive charge of the metallocene is stabilized by the tetrachloro-oxo-tetrahydrofuran-niobate(v) anion. The structure of this anion has been described previously. ${ }^{17}$ The $\mathrm{Nb}(2)-\mathrm{O}(1)$ bond distance of 1.69(1) $\AA$ is consistent with the presence of a double $\mathrm{Nb}=\mathrm{O}$ bond. The ion has four chlorine atoms arranged in the equatorial plane of the molecule at distances of $c a$. $2.39 \AA$ (see Table 1). The niobium atom is $0.29 \AA$ out of the equatorial plane formed by the four chlorine atoms, which are oriented away from the oxygen atom of the oxo ligand. The niobium atom completes its coordination sphere with a molecule of thf, with a $\mathrm{Nb}(2)-\mathrm{O}(2)$ bond length of 2.39(1) $\AA$.

The crystal is stabilized by an extensive weak hydrogeninteraction network, the geometrical features of which are shown in Table 3. A noticeable feature of this structure is the observed hydrogen-bonding interaction ${ }^{18}$ between one methyl of the (trimethylsilyl)cyclopentadienyl ring and the oxygen atom of the tetrachloro-oxo-tetrahydrofuran-niobate(v) anion, which correspond to the atoms represented as $\mathrm{C} 5-\mathrm{H} 5 \cdots \mathrm{O} 1$ in the ORTEP diagram (Fig. 3).

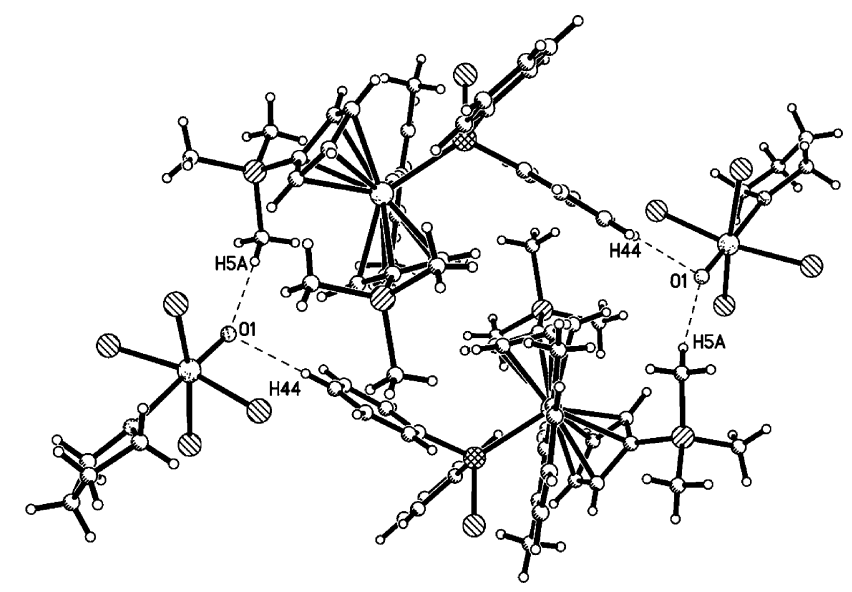

Fig. 3 Selected hydrogen bonds of complex 12. 
Table 3 Hydrogen bonds for compound $\mathbf{1 2}$

\begin{tabular}{|c|c|c|c|c|c|}
\hline D-H & $d(\mathrm{D}-\mathrm{H})(\AA ̊)$ & $d(\mathrm{H} \cdots \mathrm{A})(\AA)$ & $\angle \mathrm{DHA}\left({ }^{\circ}\right)$ & $d(\mathrm{D} \cdots \mathrm{A})(\AA)$ & Symmetry $^{a}$ \\
\hline $\mathrm{C} 5-\mathrm{H} 5 \mathrm{a} \cdots \mathrm{O} 1$ & 0.96 & 2.19 & 154.9 & $3.09(2)$ & $x, y, z$ \\
\hline $\mathrm{C} 44-\mathrm{H} 44 \cdots \mathrm{O} 1$ & 0.93 & 2.49 & 173.4 & $3.42(2)$ & $1-x, 1-y, 1-z$ \\
\hline C37-H37a $\cdots$ Cl1 & 0.96 & 2.89 & 140.8 & $3.69(1)$ & $x, y, z$ \\
\hline $\mathrm{C} 7-\mathrm{H} 7 \mathrm{c} \cdots \mathrm{Cl} 3$ & 0.96 & 2.81 & 150.4 & $3.68(1)$ & $x, y-1, z$ \\
\hline $\mathrm{C} 34-\mathrm{H} 34 \cdots \mathrm{Cl} 3$ & 0.93 & 2.76 & 156.8 & $3.63(1)$ & $2-x, 1-y, 1-z$ \\
\hline C37-H37c $\cdots \mathrm{Cl} 3$ & 0.96 & 2.82 & 148.3 & $3.67(1)$ & $x, y-1, z$ \\
\hline $\mathrm{C} 23-\mathrm{H} 23 \cdots \mathrm{Cl} 5$ & 0.98 & 2.87 & 160.0 & $3.80(1)$ & $1-x, 1-y,-z$ \\
\hline
\end{tabular}

${ }^{a}$ Symmetry operation for A.

Although some organometallic halophosphane complexes have been described previously, ${ }^{7,19-21}$ to the best of our knowledge complex 12 is the first chlorophosphanyl-metallocene complex to be characterized by $\mathrm{X}$-ray diffraction.

\section{Concluding remarks}

In conclusion, we have studied the reactivity of phosphanido complexes $\mathbf{1}$ and $\mathbf{2}$ with early transition metal halides in high oxidation states, and have successfully synthesized new homo- and heterobimetallic $\mathrm{d}^{2}-\mathrm{d}^{0}$ early-early complexes with a diphenylphosphanido-bridging moiety. Analysis of the possible conformational preferences in these complexes based on spectroscopic data was also carried out. Additionally, the formation of ionic complexes 7-10 based on cationic niobocene moieties and hexahalometallates was achieved. The molecular structures of 9 and 12 were determined by single-crystal X-ray diffraction.

\section{Experimental}

\section{General}

All reactions were carried out using Schlenk techniques. Oxygen and water were excluded through the use of vacuum lines supplied with purified $\mathrm{N}_{2}$. Toluene was distilled from sodium. Hexane was distilled from sodium/potassium alloy. All solvents were deoxygenated prior to use. Complexes $\left[\mathrm{Nb}\left(\eta^{5}-\mathrm{C}_{5} \mathrm{H}_{4} \mathrm{SiMe}_{3}\right)_{2}\left(\mathrm{PPh}_{2}\right) \mathrm{L}\right][\mathrm{L}=$ CO (1), CNXylyl (2)] were prepared by literature procedures. ${ }^{7}$ Niobium pentachloride, tantalum pentachloride, titanium tetrachloride, zirconium tetrachloride and $\left[\mathrm{Ti}\left(\eta^{5}-\mathrm{C}_{5} \mathrm{R}_{5}\right) \mathrm{Cl}_{3}\right](\mathrm{R}=\mathrm{H}$, $\mathrm{CH}_{3}$ ) were used as received from Aldrich and were manipulated in a glovebox (model MBRAUN). Deuterated solvents were supplied by SDS, dried over $4 \AA$ molecular sieves and degassed prior to use. ${ }^{1} \mathrm{H},{ }^{13} \mathrm{C}$ and ${ }^{31} \mathrm{P} \mathrm{NMR}$ spectra were recorded on a Varian Inova $500 \mathrm{MHz}$ spectrometer at ambient temperature unless stated otherwise. ${ }^{1} \mathrm{H},{ }^{13} \mathrm{C}$ and ${ }^{31} \mathrm{P}$ NMR chemical shifts ( $\delta$ values) are reported in parts per million (ppm) and trace amounts of protonated solvents $\left({ }^{1} \mathrm{H},{ }^{13} \mathrm{C}\right)$ or standard resonances $\left({ }^{31} \mathrm{P}\right.$, external $\left.85 \% \mathrm{H}_{3} \mathrm{PO}_{4}\right)$ were used as references. IR spectra in the region $200-4000 \mathrm{~cm}^{-1}$ were recorded on a Perkin-Elmer 883 spectrophotometer. The samples were prepared as Nujol mulls and the spectra were collected on Nujol/polyethylene.

\section{Preparations}

$\left[\left\{\mathrm{Nb}\left(\eta^{5}-\mathrm{C}_{5} \mathrm{H}_{4} \mathrm{SiMe}_{3}\right)_{2}(\mathrm{~L})\right\}\left(\mu-\mathrm{PPh}_{2}\right)\left(\mathrm{MCl}_{5}\right)\right], \mathrm{M}=\mathbf{N b}, \mathbf{L}=\mathbf{C O}$ (3), CNXylyl (4); M = Ta, L = CO (5), CNXylyl (6). A solution of $1(0.50 \mathrm{~g}, 0.86 \mathrm{mmol})$ or $2(0.58 \mathrm{~g}, 0.86 \mathrm{mmol})$ in anhydrous toluene $(30 \mathrm{~mL})$ was added to a cooled $\left(-78{ }^{\circ} \mathrm{C}\right)$ suspension of a stoichiometric amount of niobium pentachloride $(0.23 \mathrm{~g}$, $0.86 \mathrm{mmol})$ or tantalum pentachloride $(0.30 \mathrm{~g}, 0.86 \mathrm{mmol})(1: 1$ ratio) in the same solvent. The addition gave a deep green solution, which was allowed to reach room temperature and stirred for $1 \mathrm{~h}$. A red solid was observed in the solution after this time. The red precipitate was filtered off and dried under vacuum, yielding the new niobocene complexes $\left[\left\{\mathrm{Nb}\left(\eta^{5}-\mathrm{C}_{5} \mathrm{H}_{4} \mathrm{SiMe}_{3}\right)_{2}(\mathrm{~L})\right\}\left(\mu-\mathrm{PPh}_{2}\right)\left(\mathrm{MCl}_{5}\right)\right]$ $[\mathrm{M}=\mathrm{Nb}, \mathrm{L}=\mathrm{CO}$ (3), CNXylyl (4); M = Ta, L = CO (5), CNXylyl (6)], which were isolated as red solids in $c a .70 \%$ yield.

3. $(0.52,65 \%)$ Found: C, 39.89; H, 4.31; Calc. for $\mathrm{C}_{29} \mathrm{H}_{36} \mathrm{Cl}_{5} \mathrm{Nb}_{2} \mathrm{POSi}_{2}$ : C, 40.94; H, 4.26\%. IR (Nujol/polyethylene): $v\left(\mathrm{~cm}^{-1}\right) ; 1958(\mathrm{C} \equiv \mathrm{O})$. The low solubility of complex 3 in hydrocarbons, ethers or aromatic solvents and its high reactivity toward chloroform or dichloromethane precluded characterization by NMR techniques.

4. $(0.59 \mathrm{~g}, 80 \%)$ Found: C, 46.32; H, 4.56; N, 1.39. Calc. for $\mathrm{C}_{37} \mathrm{H}_{45} \mathrm{Cl}_{5} \mathrm{NNb}_{2} \mathrm{PSi}_{2}: \mathrm{C}, 46.58 ; \mathrm{H}, 4.75 ; \mathrm{N}, 1.47 \%$. IR $(\mathrm{Nu}-$ jol/polyethylene): $v\left(\mathrm{~cm}^{-1}\right) ; 2062(\mathrm{C} \equiv \mathrm{N}) .{ }^{1} \mathrm{H}$ NMR $\left(\mathrm{CDCl}_{3}\right): \delta$ (ppm); 0.29 (s, $\left.18 \mathrm{H}, \mathrm{Si} M e_{3}\right), 2.51$ (s, 6H, $\mathrm{CH}_{3}$ of CNXylyl), 4.58, 5.29, 5.32, $5.80\left(\mathrm{~m}, 2 \mathrm{H}, \mathrm{C}_{5} H_{4}\right), 7.89(\mathrm{~m}, 13 \mathrm{H}, P h) .{ }^{31} \mathrm{P}\left\{{ }^{1} \mathrm{H}\right\} \mathrm{NMR}$ $\left(\mathrm{CDCl}_{3}\right): \delta(\mathrm{ppm}) ; 27.4$ (s). ${ }^{31} \mathrm{P} \mathrm{NMR}\left(\mathrm{CDCl}_{3}\right): \delta(\mathrm{ppm}) ; 27.4(\mathrm{~m})$.

5. $(0.52,65 \%)$ Found: C, 36.89; H, 3.71; Calc. for $\mathrm{C}_{29} \mathrm{H}_{36} \mathrm{Cl}_{5} \mathrm{NbPOSi}_{2} \mathrm{Ta}: \quad \mathrm{C}, \quad 37.10 ; \mathrm{H}, \quad 3.86 \%$. IR (Nujol/polyethylene): $v\left(\mathrm{~cm}^{-1}\right) ; 1955(\mathrm{C} \equiv \mathrm{O}) .{ }^{1} \mathrm{H}$ NMR $\left(\mathrm{CDCl}_{3}\right)$ : $\delta(\mathrm{ppm}) ; 0.19\left(\mathrm{~s}, 18 \mathrm{H}, \mathrm{Si} M e_{3}\right), 4.58,5.31,5.57,5.65(\mathrm{~m}, 2 \mathrm{H}$, $\left.\mathrm{C}_{5} H_{4}\right), 7.05(\mathrm{~m}, 10 \mathrm{H}, P h) .{ }^{31} \mathrm{P}\left\{{ }^{1} \mathrm{H}\right\} \mathrm{NMR}\left(\mathrm{CDCl}_{3}\right): \delta(\mathrm{ppm}) ; 29.9$ (s). ${ }^{31} \mathrm{P}$ NMR $\left(\mathrm{CDCl}_{3}\right): \delta(\mathrm{ppm}) ; 29.9(\mathrm{~m})$.

6. (0.70 g, 79\%). Found: C, 42.52; H, 4.26; N, 1.28; Calc. for $\mathrm{C}_{37} \mathrm{H}_{45} \mathrm{Cl}_{5} \mathrm{NNbPSi}_{2} \mathrm{Ta}: \mathrm{C}, 42.65 ; \mathrm{H}, 4.35 ; \mathrm{N}, 1.34 \%$; IR (Nujol/polyethylene): $v\left(\mathrm{~cm}^{-1}\right) ; 2050(\mathrm{C} \equiv \mathrm{N}) .{ }^{1} \mathrm{H}$ NMR $\left(\mathrm{CDCl}_{3}\right)$ : $\delta$ (ppm); 0.21 (s, $\left.18 \mathrm{H}, \mathrm{SiMe}_{3}\right), 2.33\left(6 \mathrm{H}, \mathrm{CH}_{3}\right.$ of CNXylyl), 4.89, 5.09, 5.25, $5.67\left(\mathrm{~m}, 2 \mathrm{H}, \mathrm{C}_{5} H_{4}\right), 7.34(\mathrm{~m}, 13 \mathrm{H}, P h) .{ }^{31} \mathrm{P}\left\{{ }^{1} \mathrm{H}\right\} \mathrm{NMR}$ $\left(\mathrm{CDCl}_{3}\right): \delta(\mathrm{ppm}) ; 77.3(\mathrm{~s}) .{ }^{31} \mathrm{P}$ NMR $\left(\mathrm{CDCl}_{3}\right): \delta(\mathrm{ppm}) ; 77.3(\mathrm{~m})$.

$\left[\mathrm{Nb}\left(\eta^{5}-\mathrm{C}_{5} \mathrm{H}_{4} \mathrm{SiMe}_{3}\right)_{2}\left(\mathrm{P}(\mathrm{H}) \mathrm{Ph}_{2}\right)(\mathrm{L})\right]\left[\mathrm{MCl}_{6}\right], \mathrm{M}=\mathrm{Nb}, \mathrm{L}=\mathrm{CO}(7)$, CNXylyl (8); M = Ta, L = CO (9), CNXylyl (10). A saturated solution of complexes 3-6 ( $c a$. $1 \mathrm{mmol}$ ) in chloroform yielded red crystals after three days at room temperature. The red crystals were filtered off and dried under vacuum, yielding the new niobocene complexes $\left[\mathrm{Nb}\left(\eta^{5}-\mathrm{C}_{5} \mathrm{H}_{4} \mathrm{SiMe}_{3}\right)_{2}\left(\mathrm{P}(\mathrm{H}) \mathrm{Ph}_{2}\right)(\mathrm{L})\right]\left[\mathrm{MCl}_{6}\right][\mathrm{M}=\mathrm{Nb}, \mathrm{L}=$ CO (7), CNXylyl (8); M = Ta, L = CO (9), CNXylyl (10)].

Complexes 7-10 can also be obtained by reaction of a solution of complex $\left[\mathrm{Nb}\left(\eta^{5}-\mathrm{C}_{5} \mathrm{H}_{4} \mathrm{SiMe}_{3}\right)_{2}\left(\mathrm{P}(\mathrm{H}) \mathrm{Ph}_{2}\right)(\mathrm{L})\right] \mathrm{Cl}{ }^{7 \mathrm{a}}(\mathrm{L}=\mathrm{CO}$, 
CNXylyl) in anhydrous chloroform $(30 \mathrm{~mL})$ with stoichiometric amounts of $\mathrm{MCl}_{5}(\mathrm{M}=\mathrm{Nb}$ or Ta). The reaction mixture was stirred for $1 \mathrm{~h}$ and the resulting red precipitate was filtered off and dried under vacuum, yielding the new complexes 7-10 in ca. 90\% yield.

7 and 9: 7: (0.80 g, 90\%). Found: C, 39.55; H, 4.02; Calc. for $\mathrm{C}_{29} \mathrm{H}_{37} \mathrm{Cl}_{6} \mathrm{Nb}_{2} \mathrm{OPSi}_{2}$ : C, 39.26; H, 4.20\%. 9: (0.87 g, Yield: 90\%) Found: C, 35.47; H, 3.65; Calc. for $\mathrm{C}_{29} \mathrm{H}_{37} \mathrm{Cl}_{6} \mathrm{NbOPSi}_{2} \mathrm{Ta}$ : C, 35.71; $\mathrm{H}, 3.82 \%$; IR (Nujol/polyethylene): $v\left(\mathrm{~cm}^{-1}\right) ; 1941$ (CO), 2280 $(\mathrm{P}-\mathrm{H}) .{ }^{1} \mathrm{H}$ NMR $\left(\mathrm{CDCl}_{3}\right): \delta(\mathrm{ppm}) ; 0.07\left(\mathrm{~s}, 18 \mathrm{H}, \mathrm{Si} M e_{3}\right), 5.35$ $\left(\mathrm{m}, 4 \mathrm{H}, \mathrm{C}_{5} H_{4}\right), 5.66,6.00\left(\mathrm{~m}, 2 \mathrm{H}, \mathrm{C}_{5} H_{4}\right), 7.25\left(\mathrm{~m}, 10 \mathrm{H}, \mathrm{C}_{6} H_{5}\right)$, $7.30\left(\mathrm{~d},{ }^{1} J_{\mathrm{HP}}=367.6 \mathrm{~Hz}, \mathrm{P} H \mathrm{Ph}_{2}\right) .{ }^{13} \mathrm{C}\left\{{ }^{1} \mathrm{H}\right\} \mathrm{NMR}\left(\mathrm{CDCl}_{3}\right): \delta$ (ppm); -0.1 ( $\left.\mathrm{Si} M e_{3}\right), 97.0,98.0,99.1,99.6\left(C_{5} \mathrm{H}_{4}\right), 101.3\left(\mathrm{C}_{1}\right.$ of $\left.C_{5} \mathrm{H}_{4}\right), 129.3\left(\mathrm{~d},{ }^{3} J_{\mathrm{CP}}=9.90 \mathrm{~Hz}, C_{6} \mathrm{H}_{5}\right), 130.9\left(C_{6} \mathrm{H}_{5}\right), 132.4(\mathrm{~d}$, $\left.{ }^{2} J_{\mathrm{CP}}=9.90 \mathrm{~Hz}, C_{6} \mathrm{H}_{5}\right), 130.4\left(\mathrm{~d},{ }^{1} J_{\mathrm{CP}}=43.49 \mathrm{~Hz}, \mathrm{C}_{\text {ipso }}\right.$ of $\left.C_{6} \mathrm{H}_{5}\right)$, $250.0(\mathrm{CO}) .{ }^{31} \mathrm{P}\left\{{ }^{1} \mathrm{H}\right\} \mathrm{NMR}\left(\mathrm{CDCl}_{3}\right): \delta(\mathrm{ppm}) ; 27.6(\mathrm{~s}) .{ }^{31} \mathrm{P} \mathrm{NMR}$ $\left(\mathrm{CDCl}_{3}\right): \delta(\mathrm{ppm}) ; 27.7\left(\mathrm{~d},{ }^{1} J_{\mathrm{PH}}=367.6 \mathrm{~Hz}\right)$.

8 and 10: 8: $(0.88 \mathrm{~g}, 90 \%)$ Found: C, 45.47; H, 4.65; Calc. for $\mathrm{C}_{37} \mathrm{H}_{46} \mathrm{Cl}_{6} \mathrm{Nb}_{2} \mathrm{PSi}_{2}$ : C, 45.51; H, 4.75\%. 10: (0.96 g, Yield: 90\%) Found: $\mathrm{C}$, 41.67; $\mathrm{H}, 4.23$; Calc. for $\mathrm{C}_{37} \mathrm{H}_{46} \mathrm{Cl}_{6} \mathrm{NbPSi}_{2} \mathrm{Ta}$ : C, 41.75; $\mathrm{H}, 4.36 \%$; IR (Nujol/polyethylene): $v\left(\mathrm{~cm}^{-1}\right) ; 2280(\mathrm{P}-\mathrm{H}), 2058$ $(\mathrm{C} \equiv \mathrm{N}) .{ }^{1} \mathrm{H}$ NMR $\left(\mathrm{CDCl}_{3}\right): \delta(\mathrm{ppm}) ; 0.17$ (s, 18H, SiMe $), 2.31$ $\left[\mathrm{CN}\left(2,6-M e_{2} \mathrm{C}_{6} \mathrm{H}_{3}\right)\right], 5.36\left(\mathrm{~m}, 2 \mathrm{H}, \mathrm{C}_{5} H_{4}\right), 5.55\left(\mathrm{~m}, 2 \mathrm{H}, \mathrm{C}_{5} H_{4}\right)$, $6.65\left(\mathrm{~m}, 2 \mathrm{H}, \mathrm{C}_{5} H_{4}\right), 6.11\left(\mathrm{~m}, 2 \mathrm{H}, \mathrm{C}_{5} H_{4}\right), 7.35\left(\mathrm{~m}, 13 \mathrm{H}, \mathrm{C}_{6} H_{5}\right.$ and $\left.\mathrm{C}_{6} H_{3}\right), 8.70\left(\mathrm{~d},{ }^{1} J_{\mathrm{HP}}=387.0 \mathrm{~Hz}, \mathrm{P} H \mathrm{Ph}_{2}\right) \cdot{ }^{13} \mathrm{C}\left\{{ }^{1} \mathrm{H}\right\} \mathrm{NMR}\left(\mathrm{CDCl}_{3}\right)$ : $\delta(\mathrm{ppm}) ;-0.1\left(\mathrm{SiMe}_{3}\right), 19.4\left(\mathrm{CH}_{3}\right.$ of CNXylyl), 92.3, 100.0, 100.8, $102.4\left(C_{5} \mathrm{H}_{4}\right), 100.2\left(\mathrm{C}_{1}\right.$ of $\left.C_{5} \mathrm{H}_{4}\right), 127.6\left(\mathrm{~d},{ }^{3} J_{\mathrm{CP}}=9.83 \mathrm{~Hz}, C_{6} \mathrm{H}_{5}\right)$, $129.0\left(C_{6} \mathrm{H}_{5}\right), 133.0\left(\mathrm{~d},{ }^{2} J_{\mathrm{CP}}=9.90 \mathrm{~Hz}, C_{6} \mathrm{H}_{5}\right), 132.5\left(\mathrm{~d},{ }^{1} J_{\mathrm{CP}}=\right.$ $43.49 \mathrm{~Hz}, \mathrm{C}_{i p s o}$ of $\left.C_{6} \mathrm{H}_{5}\right), 248.0(C \mathrm{NXylyl}) .{ }^{31} \mathrm{P}\left\{{ }^{1} \mathrm{H}\right\} \mathrm{NMR}\left(\mathrm{CDCl}_{3}\right)$ : $\delta(\mathrm{ppm}) ; 38.50(\mathrm{~s}) .{ }^{31} \mathrm{P} \mathrm{NMR}\left(\mathrm{CDCl}_{3}\right): \delta(\mathrm{ppm}) ; 38.50\left(\mathrm{~d},{ }^{1} J_{\mathrm{PH}}=\right.$ $387.0 \mathrm{~Hz})$.

Synthesis of $\left[\mathrm{Nb}\left(\eta^{5}-\mathrm{C}_{5} \mathrm{H}_{4} \mathrm{SiMe}_{3}\right)_{2}\left(\mathrm{P}(\mathrm{Cl}) \mathrm{Ph}_{2}\right)(\mathrm{L})\right]\left[\mathrm{NbCl}_{4} \mathrm{O}(\right.$ thf $\left.)\right]$, $\mathbf{L}=\mathbf{C O}$ (11), CNXylyl (12). A solution of 1 (0.31 g, $0.50 \mathrm{mmol})$ or $2(0.42 \mathrm{~g}, 0.58 \mathrm{mmol})$ in anhydrous thf $(30 \mathrm{~mL})$ was added to a cooled $\left(-78{ }^{\circ} \mathrm{C}\right) 1: 1$ stoichiometric suspension of niobium pentachloride $(0.14 \mathrm{~g}, 0.50 \mathrm{mmol}$ for $1 ; 0.16 \mathrm{~g}, 0.58 \mathrm{mmol}$, for 2) in the same solvent. The reaction mixture, which was deep green, was allowed to reach room temperature and stirred for $1 \mathrm{~h}$ (until a red solid appeared). The solid was filtered off and washed twice with anhydrous hexane $(10 \mathrm{~mL})$. The red solids were dried under vacuum, yielding the new complexes $\mathbf{1 1}$ and $\mathbf{1 2}$.

Complex 11 can also be obtained by stirring a solution of complex 3 in anhydrous thf $(30 \mathrm{~mL})$ for $30 \mathrm{~min}$. The resulting red solid was filtered off and washed twice with anhydrous hexane $(10 \mathrm{~mL})$. The product was isolated in $90 \%$ yield and corresponded with complex 11.

11. (0.42 g, 90\%) Found: C, 41.98; H, 4.67; Calc. for $\mathrm{C}_{33} \mathrm{H}_{44} \mathrm{Cl}_{5} \mathrm{Nb}_{2} \mathrm{O}_{3} \mathrm{PSi}_{2}$ : C, 42.21; H, 4.72\%; Electric conductivity: $\Lambda_{\mathrm{M}}\left(\Omega^{-1} \mathrm{~cm}^{2} \mathrm{~mol}^{-1}\right) ; 116.4$. IR (Nujol/polyethylene): $v\left(\mathrm{~cm}^{-1}\right) ; 1950$ $(\mathrm{C} \equiv \mathrm{O}), 955(\mathrm{Nb}=\mathrm{O}) .{ }^{1} \mathrm{H} \mathrm{NMR}\left(\mathrm{CDCl}_{3}\right): \delta(\mathrm{ppm}) ; 0.25,0.26(\mathrm{~s}$, 9H, $\mathrm{SiMe}$ ), 1.84 (m, 4H, $\mathrm{CH}_{2}$ of thf), 3.89 (m, 4H, $\mathrm{CH}_{2} \mathrm{O}$ of thf), 4.58, 4.68, 5.30, 5.32, 5.48, $5.57\left(\mathrm{~m}, 1 \mathrm{H}, \mathrm{C}_{5} H_{4}\right), 5.67(\mathrm{~m}, 2 \mathrm{H}$, $\left.\mathrm{C}_{5} H_{4}\right), 7.39(\mathrm{~m}, 10 \mathrm{H}, P h) .{ }^{31} \mathrm{P}\left\{{ }^{1} \mathrm{H}\right\} \mathrm{NMR}\left(\mathrm{CDCl}_{3}\right): \delta(\mathrm{ppm}) ; 27.1$ (s). ${ }^{31} \mathrm{P}$ NMR $\left(\mathrm{CDCl}_{3}\right): \delta(\mathrm{ppm}) ; 27.1(\mathrm{~m})$.

12. (0.54 g, 89\%) Found: C, 47.02; H, 5.06; N, 1.31; Calc. for $\mathrm{C}_{41} \mathrm{H}_{53} \mathrm{Cl}_{5} \mathrm{NNb}_{2} \mathrm{O}_{2} \mathrm{PSi}_{2}$ : C, 47.26; $\mathrm{H}, 5.13 ; \mathrm{N}, 1.34 \%$; Electric conductivity: $\Lambda_{\mathrm{M}}\left(\Omega^{-1} \mathrm{~cm}^{2} \mathrm{~mol}^{-1}\right) ; 121.0$. IR (Nujol/polyethylene): $v\left(\mathrm{~cm}^{-1}\right) ; 2067(\mathrm{C} \equiv \mathrm{N}), 957(\mathrm{Nb}=\mathrm{O}) .{ }^{1} \mathrm{H} \mathrm{NMR}\left(\mathrm{CDCl}_{3}\right): \delta(\mathrm{ppm})$;
0.04, 0.08 (s, 9H, $\left.\mathrm{SiMe}_{3}\right), 1.85$ (m, 4H, $\mathrm{CH}_{2}$ of thf), 2.34, $2.50(3 \mathrm{H}$, $\mathrm{CH}_{3}$ of CNXylyl), 3.86 (m, 4H, $\mathrm{CH}_{2} \mathrm{O}$ of thf), 4.58, 4.86, 5.12, 5.25, 5.27, 5.33, 5.64, $5.79\left(\mathrm{~m}, 1 \mathrm{H}, \mathrm{C}_{5} H_{4}\right), 7.20(\mathrm{~s}, 2 \mathrm{H}, P h), 7.26$ (s, 3H,Ph), $7.49(\mathrm{~m}, 8 \mathrm{H}, P h) .{ }^{13} \mathrm{C}\left\{{ }^{1} \mathrm{H}\right\} \mathrm{NMR}\left(\mathrm{CDCl}_{3}\right): \delta(\mathrm{ppm})$; 0.2, $0.9\left(\mathrm{SiMe}_{3}\right), 19.1\left(\mathrm{CH}_{3}\right.$ of CNXylyl), $25.5\left(\mathrm{CH}_{2}\right.$ of thf $), 68.6$ $\left(\mathrm{CH}_{2} \mathrm{O}\right.$ of thf), 91.2, 93.0, 99.8, 100.1, 100.5, 101.1, 101.9, 102.3, $103.8\left(C_{5} \mathrm{H}_{4}\right), 128.9-132.3(P h) .{ }^{31} \mathrm{P}\left\{{ }^{1} \mathrm{H}\right\} \mathrm{NMR}\left(\mathrm{CDCl}_{3}\right): \delta(\mathrm{ppm})$; 34.2 (s). ${ }^{31} \mathrm{P}$ NMR $\left(\mathrm{CDCl}_{3}\right): \delta(\mathrm{ppm}) ; 34.2(\mathrm{~m})$.

Synthesis of $\left[\left\{\mathrm{Nb}\left(\boldsymbol{\eta}^{5}-\mathrm{C}_{5} \mathrm{H}_{4} \mathrm{SiMe}_{3}\right)_{2}(\mathrm{~L})\right\}\left(\mu-\mathrm{PPh}_{2}\right)\left(\mathrm{MCl}_{4}\right)\right], \mathbf{M}=$ Ti, L = CO (13), CNXylyl (14). An appropriate volume of titanium tetrachloride $(\rho=1.73 \mathrm{~g} \mathrm{~mL} ; 0.12 \mathrm{~g}, 0.34 \mathrm{mmol}$ for 1; $0.14 \mathrm{~g} ; 0.75 \mathrm{mmol}$ for 2$)$ was added in $1: 1$ molar ratio to a cooled $\left(-78{ }^{\circ} \mathrm{C}\right)$ solution of $1(0.21 \mathrm{~g}, 0.34 \mathrm{mmol})$ or $2(0.55 \mathrm{~g}$, $0.75 \mathrm{mmol})$ in anhydrous hexane $(30 \mathrm{~mL})$. The solution became green. The reaction mixtures were kept at low temperature for $1 \mathrm{~h}$ (until a red precipitate appeared) and were then allowed to reach room temperature. The solid was filtered off and washed twice with anhydrous hexane $(10 \mathrm{~mL})$ and dried under vacuum. Complexes $\mathbf{1 3}$ and $\mathbf{1 4}$ were isolated as orange-red and red solids, respectively, in $c a .83 \%$ yield.

13. $(0.24 \mathrm{~g}, 83 \%)$ Found: $\mathrm{C}, 45.42 ; \mathrm{H}, 4.81 \%$. Calc. for $\mathrm{C}_{29} \mathrm{H}_{36} \mathrm{Cl}_{4} \mathrm{NbOPSi}_{2} \mathrm{Ti}: \mathrm{C}, 45.22 ; \mathrm{H}, \quad 4.71 \%$. IR $(\mathrm{Nu}-$ jol/polyethylene): $v\left(\mathrm{~cm}^{-1}\right) ; 1956(\mathrm{C} \equiv \mathrm{O}) .{ }^{1} \mathrm{H}$ NMR $\left(\mathrm{CDCl}_{3}\right): \delta$ (ppm); 0.26 (s, 18H, SiMe $), 4.44,5.39,5.62,5.91$ (m, 2H, $\left.\mathrm{C}_{5} H_{4}\right)$, $7.55(\mathrm{~m}, 10 \mathrm{H}, \mathrm{Ph}) .{ }^{31} \mathrm{P}\left\{{ }^{1} \mathrm{H}\right\} \mathrm{NMR}\left(\mathrm{CDCl}_{3}\right): \delta(\mathrm{ppm}) ; 157.2(\mathrm{~s}) .{ }^{31} \mathrm{P}$ $\operatorname{NMR}\left(\mathrm{CDCl}_{3}\right): \delta(\mathrm{ppm}) ; 157.2(\mathrm{~m})$.

14. $(0.57 \mathrm{~g}, 84 \%) \mathrm{C}, 50.99 ; \mathrm{H}, 5.24 ; \mathrm{N} 1.61 \%$. Calc. for $\mathrm{C}_{37} \mathrm{H}_{45} \mathrm{Cl}_{4} \mathrm{NNbPSi}_{2} \mathrm{Ti}: \mathrm{C}, 50.88 ; \mathrm{H}, 5.19 ; \mathrm{N} 1.60 \%$. IR $(\mathrm{Nu}-$ jol/polyethylene): $v\left(\mathrm{~cm}^{-1}\right) ; 2073(\mathrm{C} \equiv \mathrm{N}) .{ }^{1} \mathrm{H} \mathrm{NMR}\left(\mathrm{CDCl}_{3}\right): \delta$ (ppm); 0.27 (s, 18H, SiMe $), 2.50\left(6 \mathrm{H}, \mathrm{CH}_{3} \mathrm{CNXylyl}\right), 4.63,5.75$ $\left(\mathrm{m}, 2 \mathrm{H}, \mathrm{C}_{5} H_{4}\right), 5.30\left(\mathrm{~m}, 4 \mathrm{H}, \mathrm{C}_{5} H_{4}\right), 7.36(\mathrm{~m}, 13 \mathrm{H}, \mathrm{Ph}) .{ }^{13} \mathrm{C}\left\{{ }^{1} \mathrm{H}\right\}$ NMR $\left(\mathrm{CDCl}_{3}\right): \delta(\mathrm{ppm}) ; 0.3\left(\mathrm{Si} M e_{3}\right), 19.5\left(\mathrm{CH}_{3} \mathrm{CNXylyl}\right), 92.3$, 100.0, 100.2, $101.3\left(C_{5} \mathrm{H}_{4}\right), 128.8,131.1,132.5,132.6(P h), 129.6$ $\left(\mathrm{d},{ }^{2} J_{\mathrm{CP}}=9.21 \mathrm{~Hz}, P h\right), 195.7(C \mathrm{~N}){ }^{31} \mathrm{P}\left\{{ }^{1} \mathrm{H}\right\} \mathrm{NMR}\left(\mathrm{CDCl}_{3}\right): \delta$ (ppm); 166.1 (s). ${ }^{31} \mathrm{P}$ NMR $\left(\mathrm{CDCl}_{3}\right): \delta$ (ppm); 166.1 (m).

Synthesis of $\left[\left\{\mathbf{N b}\left(\eta^{5}-\mathrm{C}_{5} \mathbf{H}_{4} \mathrm{SiMe}_{3}\right)_{2}(\mathrm{~L})\right\}\left(\boldsymbol{\mu}-\mathrm{PPh}_{2}\right)\left(\mathbf{M C l}_{4}\right)\right], \mathbf{M}=$ Zr, L = CO (15), CNXylyl (16). A suspension of zirconium tetrachloride $(0.16 \mathrm{~g}, 0.70 \mathrm{mmol}$ for $1,0.15 \mathrm{~g}, 0.63 \mathrm{mmol}$ for 2$)$ in anhydrous hexane was added to a cooled $\left(-78^{\circ} \mathrm{C}\right)$ solution of $\mathbf{1}$ $(0.44 \mathrm{~g}, 0.70 \mathrm{mmol})$ or $2(0.45 \mathrm{~g}, 0.63 \mathrm{mmol})$ in anhydrous hexane $(30 \mathrm{~mL})$. After the appropriate workup (see complexes 13 and 14), orange-red solids corresponding to $\mathbf{1 5}$ and $\mathbf{1 6}$ were isolated in $c a$. $80 \%$ yield.

15. $(0.50 \mathrm{~g}, \quad 81 \%)$. $\mathrm{C}, 42.81 ; \mathrm{H}, 4.71 \%$. Calc. for $\mathrm{C}_{29} \mathrm{H}_{36} \mathrm{Cl}_{4} \mathrm{NbOPSi}_{2} \mathrm{Zr}: \quad \mathrm{C}, \quad 42.93 ; \mathrm{H}, \quad 4.79 \%$; $\quad$ IR (Nujol/polyethylene): $v\left(\mathrm{~cm}^{-1}\right) ; 1949(\mathrm{C} \equiv \mathrm{O}) .{ }^{1} \mathrm{H}$ NMR $\left(\mathrm{CDCl}_{3}\right)$ : $\delta(\mathrm{ppm}) ; 0.27\left(\mathrm{~s}, 18 \mathrm{H}, \mathrm{Si} M e_{3}\right), 4.65,5.25,5.35,5.63(\mathrm{~m}, 2 \mathrm{H}$, $\left.\mathrm{C}_{5} H_{4}\right), 6.95(\mathrm{~m}, 10 \mathrm{H}, P h) .{ }^{31} \mathrm{P}\left\{{ }^{1} \mathrm{H}\right\}$ NMR $\left(\mathrm{CDCl}_{3}\right): \delta(\mathrm{ppm}) ; 28.7$ (s). ${ }^{31} \mathrm{P}$ NMR $\left(\mathrm{CDCl}_{3}\right): \delta(\mathrm{ppm}) ; 28.7(\mathrm{~m})$.

16. $(0.48 \mathrm{~g}, 81 \%)$. C, 48.82; H, 4.99; $\mathrm{N} 1.58 \%$. Calc. for $\mathrm{C}_{37} \mathrm{H}_{45} \mathrm{Cl}_{4} \mathrm{NNbPSi}_{2} \mathrm{Zr}: \mathrm{C}, 48.74 ; \mathrm{H}, 4.95 ; \mathrm{N} 1.53 \%$. IR (Nujol/polyethylene): $v\left(\mathrm{~cm}^{-1}\right) ; 2058(\mathrm{C} \equiv \mathrm{N}) \cdot{ }^{1} \mathrm{H} \mathrm{NMR}\left(\mathrm{CDCl}_{3}\right): \delta$ (ppm); 0.27 (s, 18H, SiMe $), 2.50$ (6H, $\left.\mathrm{CH}_{3} \mathrm{CNXylyl}\right), 4.70,5.29$, 5.31, $5.71\left(\mathrm{~m}, 2 \mathrm{H}, \mathrm{C}_{5} H_{4}\right), 7.24(\mathrm{~s}, 3 \mathrm{H}, P h), 7.48(\mathrm{~m}, 6 \mathrm{H}, P h), 7.54$ $(\mathrm{m}, 4 \mathrm{H}, P h) .{ }^{13} \mathrm{C}\left\{{ }^{1} \mathrm{H}\right\} \mathrm{NMR}\left(\mathrm{CDCl}_{3}\right): \delta(\mathrm{ppm}) ; 0.3\left(\mathrm{Si} M e_{3}\right), 19.5$ $\left(\mathrm{CH}_{3}\right.$ CNXylyl $), 91.6,100.1,100.3,100.8\left(C_{5} \mathrm{H}_{4}\right), 128.7,132.6$, 
132.7, 134.1 $(P h), 129.5\left(\mathrm{~d}, J_{\mathrm{CP}}=9.49 \mathrm{~Hz}, P h\right), 194.8(C \mathrm{~N}) .{ }^{31} \mathrm{P}\left\{{ }^{1} \mathrm{H}\right\}$ $\mathrm{NMR}\left(\mathrm{CDCl}_{3}\right): \delta(\mathrm{ppm}) ; 165.8(\mathrm{~s}) .{ }^{31} \mathrm{P} \mathrm{NMR}\left(\mathrm{CDCl}_{3}\right): \delta(\mathrm{ppm})$; $165.8(\mathrm{~m})$.

Synthesis of $\left[\mathbf{N b}\left(\eta^{5}-\mathrm{C}_{5} \mathrm{H}_{4} \mathrm{SiMe}_{3}\right)_{2}(\mathrm{~L})\left(\mu-\mathrm{PPh}_{2}\right)\left\{\mathrm{CTi}\left(\eta^{5}-\right.\right.\right.$ $\left.\left.\mathbf{C}_{5} \mathbf{R}_{5}\right) \mathbf{C l}_{3}\right\}$ l, $\mathbf{R}=\mathbf{H}, \mathbf{L}=\mathbf{C O}(17)$, CNXylyl (18). A solution of cyclopentadienyltrichlorotitanium(IV) $(0.13 \mathrm{~g}, 0.59 \mathrm{mmol}$ for $\mathbf{1}$, $0.15 \mathrm{~g}, 0.70 \mathrm{mmol}$ for 2$)$ in anhydrous hexane was added to a cooled $\left(-78{ }^{\circ} \mathrm{C}\right)$ solution of $1(0.36 \mathrm{~g}, 0.59 \mathrm{mmol})$ or $2(0.51 \mathrm{~g}$, $0.70 \mathrm{mmol})$ in anhydrous hexane $(30 \mathrm{~mL})$. After the appropriate workup (see complexes 13 and 14) red solids corresponding to 17 and 18 were isolated in $c a$. $86 \%$ yield.

17. $(0.42 \mathrm{~g}, 86 \%)$ Found: $\mathrm{C}, 49.12 ; \mathrm{H}, 5.02$; Calc. for $\mathrm{C}_{34} \mathrm{H}_{41} \mathrm{Cl}_{4} \mathrm{NbOPSi}_{2} \mathrm{Ti}: \mathrm{C}, 49.05 ; \mathrm{H}, 4.95 \%$. IR $(\mathrm{Nu}-$ jol/polyethylene): $v\left(\mathrm{~cm}^{-1}\right) ; 1944(\mathrm{C} \equiv \mathrm{O}) .{ }^{1} \mathrm{H}$ NMR $\left(\mathrm{C}_{6} \mathrm{D}_{6}\right): \delta$ (ppm); 0.07 (s, 18H, SiMe $), 4.28,5.31,5.60,5.94$ (m, 2H, $\mathrm{C}_{5} H_{4}$ ), $6.75\left(\mathrm{~s}, 5 \mathrm{H}, \mathrm{C}_{5} H_{5}\right), 6.89(\mathrm{~s}, 2 \mathrm{H}, P h), 7.36(\mathrm{~s}, 8 \mathrm{H}, P h) .{ }^{31} \mathrm{P}\left\{{ }^{1} \mathrm{H}\right\}$ $\operatorname{NMR}\left(\mathrm{C}_{6} \mathrm{D}_{6}\right): \delta(\mathrm{ppm}) ; 26.6(\mathrm{~s}) .{ }^{31} \mathrm{P} \mathrm{NMR}\left(\mathrm{C}_{6} \mathrm{D}_{6}\right): \delta(\mathrm{ppm}) ; 26.6$ (m).

18. $(0.57 \mathrm{~g}, 87 \%)$ Found: C, 53.63; H, 5.24; N, 1.42; Calc. for $\mathrm{C}_{42} \mathrm{H}_{50} \mathrm{Cl}_{4} \mathrm{NNbPSi}_{2} \mathrm{Ti}$ : C, 53.75; $\mathrm{H}, 5.37$; N 1.49\%. IR (Nujol/polyethylene): $v\left(\mathrm{~cm}^{-1}\right) ; 2061(\mathrm{C} \equiv \mathrm{N}) .{ }^{1} \mathrm{H}$ NMR $\left(\mathrm{C}_{6} \mathrm{D}_{6}\right): \delta$ (ppm); 0.01 (s, 18H, SiMe $), 2.14$ (s, 6H, CH $\mathrm{CHXN}_{3}$ CNyl), 4.90, 5.31, 5.34, $5.71\left(\mathrm{~m}, 2 \mathrm{H}, \mathrm{C}_{5} H_{4}\right), 6.40\left(\mathrm{~s}, 5 \mathrm{H}, \mathrm{C}_{5} H_{5}\right), 6.76(\mathrm{~s}, 4 \mathrm{H}$, $P h), 6.95(\mathrm{~s}, 2 \mathrm{H}, P h), 7.04\left(\mathrm{t}, 4 \mathrm{H}, J_{H P}=6.95 \mathrm{~Hz}, P h\right), 7.65(\mathrm{~m}$, $5 \mathrm{H}, P h) .{ }^{13} \mathrm{C}\left\{{ }^{1} \mathrm{H}\right\}$ NMR $\left(\mathrm{C}_{6} \mathrm{D}_{6}\right): \delta(\mathrm{ppm}) ; 0.3(\mathrm{SiMe}), 19.7\left(\mathrm{CH}_{3}\right.$ CNXylyl), 92.3, 100.0, 100.2, $101.3\left(C_{5} \mathrm{H}_{4}\right), 121.8\left(C_{5} \mathrm{H}_{5}\right), 127.0$, 128.7, 130.6, 131.8, $132.0(P h), 196.0(C \mathrm{~N}) .{ }^{31} \mathrm{P}\left\{{ }^{1} \mathrm{H}\right\}$ NMR $\left(\mathrm{C}_{6} \mathrm{D}_{6}\right)$ : $\delta$ (ppm): 20.1 (s). ${ }^{31} \mathrm{P}$ NMR $\left(\mathrm{C}_{6} \mathrm{D}_{6}\right): \delta(\mathrm{ppm}) ; 20.1(\mathrm{~m})$.
Synthesis of $\quad\left[\mathrm{Nb}\left(\eta^{5}-\mathrm{C}_{5} \mathrm{H}_{4} \mathrm{SiMe}_{3}\right)_{2}(\mathrm{~L})\left(\mu-\mathrm{PPh}_{2}\right)\left\{\left(\mathrm{Ti}\left(\eta^{5}-\right.\right.\right.\right.$ $\left.\left.\mathbf{C}_{5} \mathbf{R}_{5}\right) \mathbf{C l}_{3}\right\}$ ], $\mathbf{R}=\mathbf{C H}_{3}, \mathbf{L}=\mathbf{C O}$ (19), CNXylyl (20). The same procedure was performed as for the synthesis of complexes $\mathbf{1 7}$ and 18, starting with solutions of $\mathbf{1}(0.38 \mathrm{~g}$, $0.61 \mathrm{mmol})$ or $2(0.34 \mathrm{~g}, 0.47 \mathrm{mmol})$ and solutions of pentamethylcyclopentadienyltrichlorotitanium(IV) $\quad(0.18 \mathrm{~g}$, $0.61 \mathrm{mmol}$ for $\mathbf{1}, 0.13 \mathrm{~g}, 0.47 \mathrm{mmol}$ for 2). Red solids corresponding to $\mathbf{1 9}$ and $\mathbf{2 0}$ were isolated in $c a$. $87 \%$ yield.

19. $(0.48 \mathrm{~g}, 88 \%)$ Found: C, 51.92; H, 5.72; Calc. for $\mathrm{C}_{39} \mathrm{H}_{51} \mathrm{Cl}_{4} \mathrm{NbOPSi}_{2} \mathrm{Ti}: \mathrm{C}, 51.73 ; \mathrm{H}, \quad 5.68 \%$; IR $(\mathrm{Nu}-$ jol/polyethylene): $v\left(\mathrm{~cm}^{-1}\right) ; 1944(\mathrm{C} \equiv \mathrm{O}) .{ }^{1} \mathrm{H}$ NMR $\left(\mathrm{C}_{6} \mathrm{D}_{6}\right): \delta$ (ppm); 0.14 (s, 18H, SiMe $), 2.19$ (s, 15H, C $\mathrm{C}_{5}$ ), 4.48, 5.88, $5.97,6.87\left(\mathrm{~m}, 2 \mathrm{H}, \mathrm{C}_{5} H_{4}\right), 6.95\left(\mathrm{t}, 4 \mathrm{H}, J_{\mathrm{HP}}=6.59 \mathrm{~Hz}, P h\right), 7.14(\mathrm{~m}$, $4 \mathrm{H}, P h), 7.74\left(\mathrm{t}, 2 \mathrm{H}, J_{\mathrm{HP}}=8.06 \mathrm{~Hz}, P h\right) .{ }^{31} \mathrm{P}\left\{{ }^{1} \mathrm{H}\right\} \mathrm{NMR}\left(\mathrm{C}_{6} \mathrm{D}_{6}\right): \delta$ $(\mathrm{ppm}) ; 21.6(\mathrm{~s}) .{ }^{31} \mathrm{P} \mathrm{NMR}\left(\mathrm{C}_{6} \mathrm{D}_{6}\right): \delta(\mathrm{ppm}): 21.6(\mathrm{~m})$.

20. (0.41 g, 86\%) Found C, 56.05; H, 6.03; N, 1.41; Calc. for $\mathrm{C}_{47} \mathrm{H}_{60} \mathrm{Cl}_{4} \mathrm{NNbPSi}_{2} \mathrm{Ti}$ : C, 55.96; H, 6.00; N,1.39\%; IR (Nujol/polyethylene): $v\left(\mathrm{~cm}^{-1}\right) ; 2056(\mathrm{C} \equiv \mathrm{N}) .{ }^{1} \mathrm{H}$ NMR $\left(\mathrm{C}_{6} \mathrm{D}_{6}\right): \delta$ (ppm); 0.12 (s, 18H, SiMe $), 2.03$ (s, 15H, C $\mathrm{C}_{5}$ ), 2.20 (s, 6H, $\left.\mathrm{CH}_{3} \mathrm{CNXylyl}\right), 5.25,5.90\left(\mathrm{~m}, 2 \mathrm{H}, \mathrm{C}_{5} H_{4}\right), 5.69\left(\mathrm{~m}, 4 \mathrm{H}, \mathrm{C}_{5} H_{4}\right)$, $6.78(\mathrm{~s}, 3 \mathrm{H}, P h), 7.03(\mathrm{~m}, 6 \mathrm{H}, P h), 7.84(\mathrm{~m}, 4 \mathrm{H}, P h) .{ }^{31} \mathrm{P}\left\{{ }^{1} \mathrm{H}\right\}$ NMR $\left(\mathrm{C}_{6} \mathrm{D}_{6}\right): \delta(\mathrm{ppm}) ; 12.8(\mathrm{~s}) .{ }^{31} \mathrm{P}$ NMR $\left(\mathrm{C}_{6} \mathrm{D}_{6}\right): \delta(\mathrm{ppm}) ; 12.8$ (m).

\section{Crystallographic data}

Crystals of compound 9 were of poor quality. We have attempted to repeat the crystallization many times and we have mounted several crystals, but we were unable to obtain better data. However, considering the importance of the structure, it was solved despite the aforementioned problems. Data for complexes 9 and 12 were

Table 4 Crystal data and structure refinement for complexes $\mathbf{9}$ and $\mathbf{1 2}$

\begin{tabular}{|c|c|c|}
\hline Complex & 9 & 12 \\
\hline Empirical formula & $\mathrm{C}_{29} \mathrm{H}_{37} \mathrm{Cl}_{6} \mathrm{NbOPSi}_{2} \mathrm{Ta}$ & $\mathrm{C}_{41} \mathrm{H}_{53} \mathrm{Cl}_{5} \mathrm{NNb}_{2} \mathrm{O}_{2} \mathrm{PSi}_{2}$ \\
\hline MW & 975.30 & 1042.06 \\
\hline$T / \mathrm{K}$ & $250(2)$ & $180(2)$ \\
\hline Wavelength/Å & 0.71073 & 0.71073 \\
\hline Crystal system & Monoclinic & Triclinic \\
\hline Space group & $P 2_{1}$ & $P \overline{1}$ \\
\hline a/Å & $10.515(3)$ & $12.025(2)$ \\
\hline$b / \AA$ & $12.939(3)$ & $12.159(2)$ \\
\hline$c / \AA$ & $13.888(4)$ & $15.964(2)$ \\
\hline$\alpha\left({ }^{\circ}\right)$ & 90 & $90.091(2)$ \\
\hline$\beta\left({ }^{\circ}\right)$ & $95.035(6)$ & $93.465(2)$ \\
\hline$\gamma\left({ }^{\circ}\right)$ & 90 & $90.778(3)$ \\
\hline Volume $/ \AA^{3}$ & $1882.1(9)$ & $2329.5(6)$ \\
\hline$Z$ & 2 & 2 \\
\hline Density (calcd) $/ \mathrm{g} \mathrm{cm}^{-3}$ & 1.721 & 1.486 \\
\hline$\mu / \mathrm{cm}^{-1}$ & 3.764 & 0.899 \\
\hline$F(000)$ & 956 & 1064 \\
\hline Crystal size/mm & $0.43 \times 0.17 \times 0.13$ & $0.53 \times 0.25 \times 0.18$ \\
\hline \multirow[t]{3}{*}{ Index ranges } & $-9 \leq h \leq 9$ & $-12 \leq h \leq 12$ \\
\hline & $-12 \leq k \leq 12$ & $-12 \leq k \leq 12$ \\
\hline & $-12 \leq l \leq 13$ & $-16 \leq l \leq 16$ \\
\hline Reflections collected & 6395 & 10199 \\
\hline Independent reflections & $3206[R$ (int) 0.0973$]$ & $5041[R$ (int) 0.0503$]$ \\
\hline No. of data/restraints/params. & $3206 / 61 / 266$ & $5041 / 18 / 495$ \\
\hline Goodness-of-fit on $F^{2}$ & 1.044 & 1.314 \\
\hline Final $R$ indices $[I>2 \sigma(I)]$ & $R_{1}=0.0723$ & $R_{1}=0.0760$ \\
\hline Largest diff peak hole $/ \mathrm{e} \AA^{-3}$ & $\begin{array}{l}W R_{2}=0.1344 \\
0.889 \text { and }-0.509\end{array}$ & $\begin{array}{l}W K_{2}=0.2040 \\
0.973 \text { and }-1.297\end{array}$ \\
\hline
\end{tabular}


collected on a Bruker X8 APPEX II CCD-based diffractometer, equipped with a graphite-monochromated Mo-K $\alpha$ radiation source $(\lambda=0.71073 \AA)$. The crystal data, data collection, structural solution, and refinement parameters are summarized in Table 4. Data were integrated using SAINT ${ }^{22}$ and an absorption correction was performed with the program SADABS. ${ }^{23}$ The structure was solved by direct methods using SHELXTL ${ }^{24}$ and refined by fullmatrix least-squares methods based on $F^{2}$. All non-hydrogen atoms were refined with anisotropic thermal parameters (except aromatic rings in complex 9, which were refined isotropically). Hydrogen atoms were placed using a "riding model" and included in the refinement at calculated positions.

\section{Acknowledgements}

The authors gratefully acknowledge financial support from the Ministerio de Ciencia e Innovación, Spain (Grant Nos. Consolider-Ingenio 2010 ORFEO CSD 2007-00006, CTQ200800318/BQU, CTQ2009-09214), UE action COST CM0802 and the Junta de Comunidades de Castilla-La Mancha (Grant. Nos. PCI08-0010, PCIO8-0032).

\section{References}

1 (a) D. W. Stephan, Coord. Chem. Rev., 1989, 95, 41-107; (b) N. Wheatley and P. Kalck, Chem. Rev., 1999, 99, 3379-3419; (c) L. H. Gade, Angew. Chem., Int. Ed., 2000, 39, 2658-2678.

2 (a) O. Stelzer, E. Unger and V. Wray, Chem. Ber., 1977, 110, 3430-3437; (b) G. Johannsen and O. Stelzer, Chem. Ber., 1977, 110, 3438.

3 Selected examples: (a) L. Gelmini and D. W. Stephan, Organometallics, 1988, 7, 849-855; (b) A. M. Larsonneur, R. Choukroun, J. C. Daran, T. Cuenca, J. C. Flores and P. Royo, J. Organomet. Chem., 1993, 444, 83-89; (c) F. Lindenberg, T. Shribman, J. Sieler, E. Hey-Hawkins and M. Eisen, J. Organomet. Chem., 1996, 515, 187.

4 See, for example: $(a)$ P. Oudet, M. M. Kubicki and C. Moïse, Organometallics, 1994, 13, 4278-4284; (b) C. Barré, P. Boudot, M. M. Kubicki and C. Moïse, Inorg. Chem., 1995, 34, 284-291; (c) P. Sauvageot, O. Blacque, M. M. Kubicki, S. Jugé and C. Moïse, Organometallics, 1996, 15, 2399-2403; (d) G. Boni, P. Sauvageot, E. Marplaux and C. Moïse, Organometallics, 1995, 14, 5652-5656.

5 S. Leelasubcharoen, P. A. Zhizhko, L. G. Kuzmina, A. V. Churakov, J. A. K. Howard and G. I. Nikonov, Organometallics, 2009, 28, 4500 4506.
6 S. Blaurock and E. Hey-Hawkins, Eur. J. Inorg. Chem., 2002, 2975 2984.

7 (a) A. Antiñolo, F. Carrillo, J. Fernández-Baeza, S. García-Yuste, A. Otero, J. Sanchez-Prada and E. Villaseñor, Eur. J. Inorg. Chem., 2000, 1437-1443; (b) A. Antiñolo, D. Evrard, S. Garcia-Yuste, A. Otero, J. C. Pérez-Flores, R. Reguillo- Carmona, A. M. Rodriguez and E. Villaseñor, Organometallics, 2006, 25, 3670-3677; (c) A. Antiñolo, S. García-Yuste, A. Otero, J. C. Pérez-Flores, R. Reguillo-Carmona, A. M. Rodríguez and E. Villaseñor, Organometallics, 2006, 25, 13101316.

8 A. Antiñolo, S. García-Yuste, I. López-Solera, A. Otero, J. C. PérezFlores, R. Reguillo-Carmona, E. Villaseñor, E. Santos, E. Zuidema and C. Bo, Dalton Trans., 2010, 39, 1962-1971.

9 M. Y. Darensbourg, C. J. Bischoff, S. A. Houliston, M. Pala and J. Reibenspies, J. Am. Chem. Soc., 1990, 112, 6905-6912.

10 (a) N. A. Ketterer, J. W. Ziller, A. L. Rheingold and A. F. Heyduk, Organometallics, 2007, 26, 5330-5338; (b) T. Thomas, D. Pugh, I. P. Parkin and C. J. Carmalt, Dalton Trans., 2010, 39, 5325-5331; (c) H. Braunschweig, K. Radacki and K. Schwab, Chem. Commun., 2010, 46, 913-915.

11 See for example: T. T. Nadasdi and D. W. Stephan, Inorg. Chem., 1993, 32, 5933-5838.

12 W. J. Geary, Coord. Chem. Rev., 1971, 7, 81-122.

13 H. O. Davies, A. C. Jones, M. A. Motevalli, E. A. McKinnell and P. O'Brien, Inorg. Chem. Commun., 2005, 8, 585-587.

14 F. Marchetti, G. Pampaloni and T. Repo, Eur. J. Inorg. Chem., 2008, $2107-2112$.

15 (a) F. A. Cotton and R. Poli, Polyhedron, 1987, 6, 2181-2186; (b) J. H. Matonic, S. Chen, L. E. Pence and K. R. Dunbar, Polyhedron, 1992, 11, 541-546.

16 V. P. Morgalyuk, P. V. Petrovskii, K. A. Lysenko and E. E. Nifant'ev, Russ. J. Gen. Chem., 2010, 80, 100-105.

17 See for example: H. C. Aspinall, M. M. Roberts and S. J. Lippard, Inorg. Chem., 1984, 23, 1782-1784.

18 J. Emsley, Chem. Soc. Rev., 1980, $9,91$.

19 C. A. McAuliffe, S. M. Godfrey, A. G. Mackie and R. G. Pritchard, Angew. Chem., Int. Ed. Engl., 1992, 31, 919-921.

20 F. A. Cotton and P. A. Kibala, J. Am. Chem. Soc., 1987, 109, 33083312.

21 G. V. Gridunova, V. E. Shklover, Y. T. Struchkov, V. D. Vil'chevskaya, N. L. Podobedova and A. I. Krylova, J. Organomet. Chem., 1982, 238, 297-305.

22 SAINT+ v7.12a. Area-Detector Integration Program, Bruker-Nonius AXS, Madison, Wisconsin, USA, 2004.

23 G. M. Sheldrick, SADABS version 2004/1. A Program for Empirical Absorption Correction, University of Göttingen, Göttingen, Germany, 2004.

24 SHELXTL-NT version 6.12, Structure Determination Package, BrukerNonius AXS, Madison, Wisconsin, USA, 2001. 